\title{
The Optimal Mix of Bank and Market Debt: An Asset Pricing Approach*
}

\author{
Dirk Hackbarth Christopher A. Hennessy Hayne E. Leland
}

February 5, 2003

\begin{abstract}
This paper examines the optimal mix and priority structure of bank and market debt using a tax shield-bankruptcy cost tradeoff model where the only unique feature of banks is their ability to renegotiate. Closed-form expressions are derived for the values of renegotiable bank debt, non-renegotiable market debt, equity, and levered firm values. Optimal debt structure hinges upon ex post bargaining power. Weak firms utilize bank debt exclusively. Strong firms use a mixture of bank and market debt, with bank debt senior. The model explains: (i) why small firms use bank debt exclusively; (ii) why large firms employ mixed debt financing; (iii) why bank debt is senior; and (iv) why firms shift from bank debt into a mixture of market and bank debt over their life-cycle. The optimal debt contracts entail Absolute Priority, and we provide estimates of the cost of ex post priority violations across creditor classes.
\end{abstract}

JEL Codes: G13, G32, G33.

Keywords: Banking, Capital Structure, Priority Structure, and Contingent Claims Pricing.

${ }^{*}$ Walter A. Haas School of Business, U.C. Berkeley. We would like to thank seminar participants at the University of Arizona, U.C. Berkeley, and Stanford University where early versions of this paper were presented. Special thanks to Paul Pfleiderer for detailed comments and suggestions. 


\section{Introduction}

Following Modigliani and Miller's (1958) irrelevance result, the corporate tax shield provided by debt was cited as an important determinant of capital structure. More recently, contract theorists have questioned the utility of the tax shield in resolving the capital structure puzzle. For instance, Hart and Moore (1995) argue that, "these approaches cannot explain the types of debt claims observed in practice." ${ }^{1}$ This paper demonstrates that reports of the tax shield's demise are premature, and that, in fact, the debt tax shield is sufficient to explain many of the stylized facts with respect to debt structure that are central to the banking and contracting literatures.

The optimal debt structure maximizes ex ante firm value. Employing a continuous-time asset pricing framework, we paper identify the optimal priority structure and mixture of renegotiable debt (bank and privately placed debt) and non-renegotiable (market) debt. ${ }^{2}$ Debt mix and priority structure determine the value of tax shields, bankruptcy costs, and renegotiation costs. Analytical solutions are derived for bank debt, market debt, equity, and levered firm values as functions of the endogenous variables (promised coupons and priority structure) and exogenous parameters (ex post bargaining power, underlying volatility, tax rates, renegotiation costs, and bankruptcy costs). Absolute Priority (AP) across creditor classes is optimal in our setting, and we estimate the $e x$ ante costs of anticipated deviations from AP across creditor classes.

Optimal debt structure hinges upon the division of ex post bargaining power between the firm and bank. We consider two polar cases. Strong Firms have full bargaining power in renegotiations and engage in strategic default, making take-it-or-leave-it offers over debt service and capturing all bilateral surplus. ${ }^{3}$ In contrast, Weak Firms receive take-it-or-leave-it offers from the bank in renegotiations, implying the bank extracts all bilateral surplus. For this reason, we label the bank debt obligations of strong and weak firms Equity Power Debt (EPD) and Bank Power Debt (BPD), respectively. In the model, firms can choose the optimal mix of market and bank debt, but cannot choose the type of bank debt they issue. That is, in terms of their bank debt commitments, strong and weak firms are constrained to issue EPD and BPD, respectively. Bargaining power is treated as a "fact of life" for the firm, since an agreement to be weak is not incentive compatible

\footnotetext{
${ }^{1}$ Hart (1993) makes the same argument.

${ }^{2}$ The term "bank debt" is adopted as a shorthand for all renegotiable debt including private placements.

${ }^{3}$ The term strategic default is borrowed from Anderson and Sundaresan (1996) and Mella-Barral and Perraudin (1997).
} 
ex post. It is most natural to think of weak firms as being relatively small or young corporations that are possibly locked into a relationship with a single bank, an interpretation consistent with the motivation provided by Rajan (1992).

The model generates several predictions that are consistent with the stylized facts. First, weak firms find it optimal to finance exclusively with bank debt. That is, for weak firms, bank debt dominates any mix of market and bank debt, regardless of the priority structure under the proposed mixed debt policy. This result holds in the absence of any notion of monitoring or certification by banks, transaction costs, economies of scale, and other common rationales for why small firms fail to tap public debt markets. Second, the optimal debt structure for strong firms entails a mixture of bank and market debt, thus providing a rationale for the coexistence of both types of debt within the capital structure of a single firm. Third, while employing a mixed debt structure, strong firms optimally place bank debt senior in priority.

To the extent that one views young firms as having a weak ex post bargaining position vis-à-vis banks, and gaining bargaining strength as they mature, the model generates a tax-based life-cycle hypothesis for debt structure. Young firms begin by relying exclusively on bank debt. As they grow and gain bargaining power, they shift away from bank debt, placing more reliance on market debt. This prediction is consistent with observed financing patterns, and is not dependent on bank certification of young firms. In fact, the model predicts that even if a weak firm could tap public debt markets with fair pricing, it would be sub-optimal to do so.

The intuition for our results is as follows. First, consider optimal debt structure when the firm has full ex post bargaining power. Bank debt offers the advantage of being renegotiable in bad states, implying lower bankruptcy costs than those associated with market debt. However, the strong firm has limited bank debt capacity. Since the firm can make take-it-or-leave-it offers to the bank, the initial value of bank debt cannot exceed the bank's threat point in renegotiations, where the threat point is equal to bank recoveries in the event of reorganization. In order maximize its bank debt capacity, the strong firm places the bank senior in priority. Market debt is shown to complement bank debt. Although market debt entails higher default costs, it does not suffer from the strategic default problem. Consequently, market debt allows the firm to increase the value of the debt tax shield above that attainable under exclusive bank debt finance. As is standard, the optimal coupon on market debt equates marginal bankruptcy costs and tax shield benefits. 
In contrast, weak firms find it optimal to finance entirely with bank debt. This is because issuance of market debt only creates costs for the weak firm without offering countervailing benefits. To see this, note that the weak firm does not suffer from the strategic default problem and is able to increase the value of the debt tax shield with a higher coupon on its bank debt. While offering no tax shield benefit beyond what is attainable with exclusive bank debt finance, market debt entails a cost. In particular, the existence of market debt causes bilateral renegotiations between the bank and firm to be inefficient, leading to premature reorganization. Consequently, the weak firm relies upon bank debt exclusively.

A secondary objective is to bridge the divide between the banking and continuous-time corporate finance literatures. While we demonstrate that the traditional tax shield-bankruptcy cost tradeoff theory is consistent with many of the stylized facts the banking literature seeks to explain, unifying the two literatures offers the potential for making strides in explaining capital structure. For instance, introducing moral hazard in the form of asset substitution and endogenous monitoring are all feasible within a structural pricing framework. In addition to generating new qualitative predictions of the sort provided in this paper, the asset pricing approach produces precise quantitative predictions which are useful in taking theory to the data.

The remainder of the paper is organized as follows. Section II contains a review of related empirical and theoretical papers. Section III presents the basic model. Section IV analyzes optimal debt structure when the bank has full bargaining power. Section V analyzes senior bank debt when equity has full bargaining power. Section VI analyzes junior bank debt when equity has full bargaining power. Section VII evaluates costs of deviations from AP.

\section{Literature Review}

Our paper represents the first structural pricing model allowing the firm to issue both renegotiable and non-renegotiable debt. From the perspective of bringing theory into alignment with empirical evidence, this is an important exercise. In their study of large publicly traded firms, Houston and James (1996) find that the mean percentage of market debt in total debt is $17 \%$, with $54 \%$ of their sample relying exclusively on non-market debt. For those firms issuing market debt, the mean and median percentage of market debt in total debt is $34 \%$ and 40\%, respectively. Johnson (1997) 
studies the ownership structure of long-term debt, with $47 \%$ of his sample issuing market debt. For those firms issuing market debt, the mean and median percentage of market debt in total long-term debt is $56 \%$ and $59 \%$, respectively. Johnson concludes, "The systematic use of bank debt by firms with access to public debt implies that their reputations are not perfect substitutes for monitoring, or that there are other factors that make bank debt attractive for them." 4

It is well documented that bank debt is typically senior in priority. Carey (1995) finds that in the 18,000 loans made between 1986 and 1993 and recorded in the Dealscan database, over 99\% of all bank loans contain a seniority clause. Mann (1997) and Schwartz (1997) find that in addition to taking senior positions, banks collateralize as much of their debt holdings as possible. Our model generates predictions consistent with these stylized facts regarding debt mix and priority structure.

We offer here a brief survey of continuous-time corporate finance papers that are most closely related to our model. Leland (1994) solves for optimal leverage when the firm may only issue nonrenegotiable debt. Anderson and Sundaresan (1996), Mella-Barral and Perraudin (MBP, 1997), Hege and Mella-Barral (HMB, 2000), and Hege and Mella-Barral (HMB, 2002) consider optimal leverage when the firm may only issue renegotiable debt. Fan and Sundaresan (2000) characterize two Nash bargaining formulations in which equity and debt bargain over the value of the assets of the firm (debt-equity swap) or over the value of the firm (strategic debt service).

There is a connection between our results on optimal debt mix and priority and recent structural pricing models dealing with exclusive renegotiable debt finance. MBP (1997) and HMB (2000) show that in the presence of a corporate income tax, a firm constrained to issuing renegotiable debt would optimally distribute all bargaining power to the bank if commitment were feasible. We prove a complementary result, showing that if full bank bargaining power is indeed feasible, the firm will rely exclusively upon bank debt, even when it has the option to tap public debt markets. ${ }^{5}$ More recently, HMB (2002) demonstrate that when equity holds full ex post bargaining power, issuance of renegotiable debt to dispersed creditors (as opposed to a single creditor) increases firm value. Intuitively, dispersed atomistic bondholders are tougher in ex post renegotiations due to the free-rider problem. Taken together, our paper and HMB (2002) suggest that seniority and

\footnotetext{
${ }^{4}$ See Krishnaswami, Spindt, and Subramaniam (1999) and Denis and Mihov (2002) for related empirical studies.

${ }^{5}$ Both debt sources are assumed to be fairly priced with no issuance costs or liquidity benefits.
} 
dispersion of creditors represent alternative devices for mitigating the erosion of the debt tax shield created by strategic default.

Moving outside the continuous-time literature, a number of papers have addressed the choice between market and bank debt, with the choice being treated as mutually exclusive. Building on Diamond (1989), Diamond (1991) presents a model in which reputational capital serves to mitigate the asset substitution problem. Mature firms, with high reputational capital, rely on market debt, while young firms, with low reputational capital, utilize banks for the purpose of monitoring and certification. Chemmanur and Fulghieri (1994) show that banks have a higher incentive to acquire reputations for making ex post efficient liquidation decisions. Consequently, firms with a high probability of distress rely on bank debt, while healthy firms rely upon cheaper public debt. ${ }^{6}$ Cantillo and Wright (2000) use a costly state verification framework to analyze the choice between market and bank debt over the business cycle.

A number of contracting papers allow the firm to issue a mix of market and bank debt, allowing them to make qualitative predictions regarding debt mix, priority and/or maturity. Diamond (1993b) finds that senior bank debt is optimal, since placing the bank junior results in excessive continuation. Berglöf and von Thadden (1994) evaluate optimal debt structure when cash-flows are non-verifiable, creating strategic default problems. The optimal debt contract maximizes the short-term lender's incentive to liquidate, implying it is optimal to place the short-term lender senior. Our paper is closely linked to Diamond (1993b) and Berglöf and von Thadden (1994) in that each paper uses seniority as a device for making the lender tough in renegotiations. A similar parallel exists between HMB (2002) and Bolton and Scharfstein (1996), with those papers relying on multiple creditors to increase ex post toughness.

Rajan (1992) demonstrates that if a bank develops an informational monopoly over a firm, it can demand a share of the surplus from profitable projects as a condition for rolling over short-term loans, thus diminishing managerial effort. In order to reduce the bargaining power of informed lenders, the firm grants uninformed lenders higher priority. Diamond (1993a), shows that allowing dilution of junior long-term debt when new information is revealed allows good firms to increase the informational sensitivity of financing costs. Recent papers by Park (2000) and Gorton and

\footnotetext{
${ }^{6}$ Bolton and Freixas (2000) make a similar argument.
} 
Kahn (2000) rationalize the seniority of bank debt based on monitoring incentives. ${ }^{7}$ Finally, Welch (1997) analyzes the role of influence costs, which are those costs associated with creditor classes competing for a larger slice of the pie in default. Placing bank debt senior is optimal in his model since influence costs are lower when the strongest creditor, ex post, is given more power ex ante.

While much of the banking literature focuses on optimal priority, Franks and Torous (1989, 1994) and Weiss (1990) find that adherence to AP is the exception, not the rule. A substantial number of papers in the law and finance literature have attempted to rationalize deviations from AP as beneficial due to mitigation of moral hazard problems. See Bebchuk (2002) for a recent survey, and a dissenting view. These papers share the trait that the costs and benefits of deviations from $\mathrm{AP}$ are driven by the treatment of equity. In contrast, we show that deviations from AP across creditor classes is costly. In addition, the use of an asset pricing framework allows us to quantify the magnitude of such costs.

\section{The Model}

The underlying state variable $X$ is the firm's EBIT. Following Berglöf and von Thadden (1994) and Hart and Moore (1995), $X$ is observable but non-verifiable. ${ }^{8}$ EBIT follows a geometric Brownian motion:

$$
d X_{t}=\mu X_{t} d t+\sigma X_{t} d W_{t}, \quad X_{0}>0
$$

where $\mu$ and $\sigma$ are known positive constants and $W$ is a Wiener process under the physical measure. All agents are risk neutral, and there is a risk-free asset yielding a constant rate of return $r>\mu$.

Within this setting, consider an arbitrary claim paying the state contingent flow $m X+k$. The value function $(G)$ for the claim must satisfy the following ODE:

$$
\frac{1}{2} \sigma^{2} X^{2} G^{\prime \prime}(X)+\mu X G^{\prime}(X)-r G(X)+m X+k=0 .
$$

The general solution to this ODE is:

$$
G(X)=K_{1} X^{a}+K_{2} X^{z}+\frac{m X}{r-\mu}+\frac{k}{r}
$$

\footnotetext{
${ }^{7}$ Fama (1990) argues that junior lenders have greater monitoring incentives, implying banks should be junior.

${ }^{8}$ If an EBIT contingent contract could be enforced, and treated as debt by the tax authority, the first-best is achieved by pledging all cash-flow to the lender.
} 
where $a<0$ and $z>1$ denote the roots of the quadratic:

$$
Q(a) \equiv \frac{1}{2} \sigma^{2} a^{2}+\left(\mu-\frac{1}{2} \sigma^{2}\right) a-r=0 .
$$

All of the contingent claims priced below have solutions of this form, with suitable boundary conditions pinning down unknown constants.

There is a linear tax at rate $\tau \in(0,1)$ levied on corporate income, which is computed as EBIT less instantaneous debt service. Following Leland (1994), the parameter $\tau$ is interpreted as the effective corporate tax shield, taking into account individual income tax differentials on debt and equity income. Based on the analysis of Graham (2000), our baseline numerical results assume $\tau=20 \%$. It is never optimal to shut-down an unlevered firm since cash-flows are positive, and the implied value of the unlevered corporation at any instant is given by $V$ :

$$
V(X)=\frac{(1-\tau) X}{r-\mu}
$$

The firm may issue two classes of consol bond debt: bank debt, with promised flow coupon $b$, and market debt with promised flow coupon $c$. As in Hart and Moore (1995), we assume that Market Debt (MD) cannot be renegotiated. There are two rationales for this assumption. First, with widely dispersed creditors, the costs of renegotiating such debt may be prohibitive. Second, as discussed in Smith and Warner (1979), public debt is subject to the Trust Indenture Act of 1939, which places stringent conditions on restructurings. Within the model, failure to pay the promised coupon on MD leads to immediate reorganization. It is in this sense that MD represents what Hart and Moore (1995) would term a "hard claim."

In contrast, bank debt may be renegotiated, with the character of the debt service depending on the bargaining power of the firm vis-à-vis the bank, as well as the parties' respective threat points. As stated in the introduction, we distinguish between two types of firms. Strong Firms have full bargaining power in renegotiation and we label their bank debt obligations Equity Power Debt (EPD). Weak Firms face a bank that holds all bargaining power, and we label their bank debt obligations Bank Power Debt (BPD).

For the remainder of the paper, the term default states refers to situations in which either MD is not serviced or in which the firm and bank fail to reach agreement on debt service, with either event leading to immediate reorganization. States in which equity fails to make the promised bank 
coupon payment $(b)$ but enters into successful renegotiations with the bank, with any required MD coupon service being paid, are referred to as renegotiation states.

Following Leland (1994), there is a deadweight loss in the event of reorganization, with the parameter $\alpha \in(0,1)$ representing net default costs as a percentage of unlevered firm value. The value of the reorganized firm is denoted $L$, with:

$$
L(X) \equiv(1-\alpha) V(X)
$$

Unless otherwise stated, the working assumption is that there are no frictions in the renegotiation process. However, we evaluate the sensitivity of our results to the existence of renegotiation costs in the numerical analysis. The flow renegotiation cost is equal to a constant $\delta \in[0,1-\tau]$ multiplied by the difference between promised bank debt service $(b)$ and actual debt service paid. ${ }^{9}$

The optimal debt structure maximizes total firm value at date zero. The value of the marketable claims of the levered firm $(v)$ is equal to the sum of the values of equity $(E)$, market debt $(C)$, and bank debt $(B)$ :

$$
v(X)=E(X)+C(X)+B(X) .
$$

\section{Weak Firm}

Recall, the weak firm is faced with a bank that has full ex post bargaining power in renegotiations, with the corresponding debt obligation labeled Bank Power Debt (BPD). In this section we demonstrate that the weak firm finds it optimal to finance exclusively with bank debt.

As a first-step in the analysis, we characterize the bank debt service for the weak firm. Following MBP (1997), attention is confined to debt service functions that are piecewise right-continuous. With BPD, in the event that equity fails to pay $b$ and chooses to enter into renegotiation, it is the bank that makes take-it-or-leave-it offers. In renegotiation, equity is pushed down to its reservation value, which is zero under limited liability. Since equity value is everywhere zero on the renegotiation region, satisfaction of (2) implies the cash-flow to equity is zero in renegotiation states. That is, in renegotiation states, equity pays all cash-flow, $X-c$, to the bank. Equity chooses to enter

\footnotetext{
${ }^{9}$ The upper bound on $\delta$ ensures the cash-flow to equity is decreasing in debt service paid.
} 
into renegotiation at the first-passage of $X$ from above to its endogenous renegotiation threshold, denoted as $X_{n}(b, c)$.

Since the cash-flow to equity is zero in renegotiation states under BPD, it is the lender who must pay any instantaneous renegotiation costs. The cash-flow to the bank on the renegotiation region is therefore equal to:

$$
X-c-\delta[b-(X-c)]^{+}
$$

So long as the bank is willing to service the MD coupon commitment $(c)$ as well as pay any renegotiation costs, equity is just willing to continue and reorganization is avoided. Consequently, for the weak firm, it is the bank that effectively chooses when to reorganize, since the decision by the bank not to cover MD coupon brings about immediate default on the part of equity. The bank's endogenous reorganization threshold under BPD is denoted $X_{b}(b, c)$. Figure 1 illustrates the nature of the conjectured equilibrium under BPD if renegotiation costs are zero.

In contrast to the analysis of the weak firm provided above, Section V shows that for firms financed with MD exclusively and strong firms financed with a mixture of MD and EPD, it is equity that chooses the reorganization threshold by declaring default. The corresponding default threshold is denoted $X_{e}(b, c)$. Lemma 1 proves that when the firm is weak, equity's endogenous renegotiation threshold $\left(X_{n}\right)$ under the mixed debt policy $(b, c)$ is identical to the default threshold $\left(X_{e}\right)$ chosen by equity in a firm financed exclusively with MD carrying the coupon $b+c$. Intuitively, from the perspective of equity, there is no difference between default and entering into renegotiations with a bank that has full bargaining power, since both outcomes generate an equity claim worth zero.

Lemma 1 For the Weak Firm issuing the Bank Power Debt-Market Debt pair (b, c), equity's renegotiation threshold $\left(X_{n}\right)$ is equal to the default threshold $\left(X_{e}\right)$ chosen by equity under exclusive Market Debt issuance carrying the coupon $b+c$. That is:

$$
X_{n}(b, c)=X_{e}(0, b+c)=\left(\frac{r-\mu}{r}\right)\left(\frac{a}{a-1}\right)(b+c) .
$$

Proof. The cash-flow to equity in non-renegotiation states under BPD for the pair $(b, c)$ is identical to that under exclusive MD finance with coupon $\bar{c}=b+c$. Default on MD and 
renegotiation of BPD entail a zero payoff. Result follows from the fact that the respective stoppingtime problems employ the same boundary conditions:

$$
\begin{aligned}
E\left[X_{n}(b, c)\right] & =E\left[X_{e}(0, \bar{c})\right]=0 \\
E^{\prime}\left[X_{n}(b, c)\right] & =E^{\prime}\left[X_{e}(0, \bar{c})\right]=0 .
\end{aligned}
$$

The default threshold $X_{e}$ is derived below in (38).

\section{A. Optimal Debt Structure for a Weak Firm}

Proposition 2 proves that the optimal financial policy for a weak firm entails financing with bank debt exclusively. This result holds regardless of the assumed values of the parameters $(\tau, \alpha, \sigma, \delta)$ and regardless of the assumed priority structure on any proposed mixed debt financing arrangement. In the remainder of the paper, $\mathbf{T}$ denotes the set of all stopping times under the natural filtration generated by $X$.

Proposition 2 For the Weak Firm, exclusive Bank Debt finance dominates any policy involving nonzero Market Debt, regardless of priority structure.

Proof. Optimal debt policy maximizes $v$. Consider an arbitrary mixed policy $(b, c)$ and priority rule $f: \Re_{+} \longrightarrow \Re_{+}$mapping reorganized firm values $(L)$ into bank recoveries. Now consider the pure BPD policy with $\bar{b}=b+c$. From Lemma 1 , equity values in the two firms are equal $\forall \mathrm{X}$. The mixed debt firm has bank debt service $s$ and claim values $(B, C)$. Let $\bar{s}$ denote debt service and $\bar{B}$ bank debt value under pure BPD finance. Note that in non-reorganization states, $\bar{s}(X)=s(X)+c$. On this same region, flow renegotiation costs are identical and equal to $\delta[\bar{b}-\bar{s}(X)]^{+}$. The stopping time problem for the bank under pure $\mathrm{BPD}$ is:

$$
\bar{B}\left(X_{0}\right) \equiv \max _{T \in \mathbf{T}} \mathbf{E}_{0}\left[\int_{0}^{T} e^{-r t}\left[\bar{s}\left(X_{t}\right)-\delta\left(\bar{b}-\bar{s}\left(X_{t}\right)\right)^{+}\right] d t+e^{-r T} L\left(X_{T}\right)\right] .
$$

The stopping time problem for the bank under mixed debt is:

$$
B\left(X_{0}\right) \equiv \max _{T \in \mathbf{T}} \mathbf{E}_{0}\left[\int_{0}^{T} e^{-r t}\left[s\left(X_{t}\right)-\delta\left(b-s\left(X_{t}\right)\right)^{+}\right] d t+e^{-r T} f\left(L\left(X_{T}\right)\right)\right] .
$$


Let $T_{m}^{*} \equiv \inf \left\{t \geq 0: X_{t}=X_{b}(b, c)\right\}$ represent the optimal stopping time for the bank under the mixed debt policy. Using the fact that recoveries in default sum to $L$, the equality of renegotiation costs, and the fact that $\bar{s}(X)=s(X)+c$ in non-reorganization states we have:

$$
B\left(X_{0}\right)+C\left(X_{0}\right)=\mathbf{E}_{0}\left[\int_{0}^{T_{m}^{*}} e^{-r t}\left[\bar{s}\left(X_{t}\right)-\delta\left(\bar{b}-\bar{s}\left(X_{t}\right)\right)^{+}\right] d t+e^{-r T_{m}^{*}} L\left(X_{T_{m}^{*}}\right)\right] \leq \bar{B}\left(X_{0}\right) .
$$

Proposition 2 suggests the following intuition for the dominance of pure bank debt finance for weak firms. For any mixed debt policy $(b, c)$, the weak firm can achieve the same equity valuation by issuing BPD with coupon $\bar{b}=b+c$. However, since it is the bank that effectively decides when to reorganize, through its choice of $X_{b}$, it is optimal to avoid ex post inefficient bank decision rules that emerge when the choice of $X_{b}$ generates an externality to other classes of debt. Similarly, BPD dominates pure MD finance since BPD contains the option not to reorganize at $X_{n}=X_{e}$, and this option has weakly positive value ex post. In light of the result that follows in Lemma 3 , it is important to stress that the optimality of exclusive bank debt finance for the weak firm is not driven by reliance on extreme leverage ratios. Rather, given any total promised coupon, it is optimal for the weak firm to use bank debt exclusively.

Proposition 2 is similar in spirit to the papers by Berlin and Loeys (1988), Chemmanur and Fulghieri (1994), and Cantillo and Wright (2000) which emphasize banks as making superior liquidation decisions. However, the logic of the argument is most similar to that advanced by Gertner and Scharfstein (1991), who analyze the effect of non-renegotiable debt in the context of debt workouts. In their model, externalities accruing to non-renegotiable debt distort bilateral renegotiations between equity and the bank, resulting in underinvestment and asset substitution problems.

As a curiosity, we now examine what would happen in a world with frictionless renegotiation if the tax authority were sleeping on the job. In particular, Lemma 3 shows that absent renegotiation costs and limitations on interest deductions, the weak firm can achieve first-best.

Lemma 3 Absent renegotiation costs $(\delta=0)$, the Weak Firm attains the first-best value $\frac{X_{0}}{r-\mu}$ by financing exclusively with Bank Debt and setting an arbitrarily high coupon b. Taxes are eliminated and bankruptcy costs are zero. 
We now sketch the logic of Lemma 3. Note that in renegotiation states the payment to the bank is equal to $X$ which has positive support. Therefore, the bank never induces costly reorganization. Further, in renegotiation states, all taxable income is offset by interest expense, thus eliminating taxes. The optimal debt structure induces renegotiation in all states by setting an arbitrarily high promised coupon.

While this frictionless bargaining framework is stylized, it does approximate the highly levered transactions that caused considerable concern for the U.S. Treasury during the heyday of the high-yield market. For instance, in calling for limitations on interest deductions in highly levered restructurings, Bulow, Summers, and Summers (BSS) (1990) argued that, "financial innovation has reduced the difference between the investment characteristics of debt and equity. Firms are now able to issue securities that function very much like equity but are treated as debt for tax purposes." As a defense against what BSS label "equity in drag," the tax courts have relied upon five factors that distinguish debt: 1) divergence of interest between debt and equity; 2) debt to equity ratio less than $10: 1$; 3) written unconditional promise to make a certain payment; 4) debt senior to equity; and 5) convertibility provisions represent less than half the value of the instrument. Note that in employing the first factor, tax law implicitly assumes debt-equity conflicts will generate default costs and limit the use of debt. However, this view ignores the Coase Theorem, which indicates that ex post renegotiations eliminate inefficiencies. In particular, the model shows how the firm is able to eliminate tax liability and default costs in the context of a bona fide conflict of interest between equity and debt.

The optimal leverage ratios generated by the model are in excess of those observed for smaller firms. The addition of renegotiation costs moves the model away from the $100 \%$ bank debt prediction contained in Lemma 3, but the implied leverage ratios are still high. A number of potential explanations are available. First, the model assumes a linear tax schedule, thus overstating the value of the debt tax shield. Second, firms may be wary of testing the tax authorities in light of the debt to equity ratio test that is part of the case law defining debt. Third, alternative specifications of the bargaining process, such as those allowing for the possibility of complete break-down, would imply lower leverage ratios. Fourth, the arguments in Rajan (1992) suggest that allowing the bank to capture all surplus, while desirable from a tax perspective, would generate heavy costs for firms 
in which managerial effort is an important determinant of value. Finally, managers will limit debt issuance when they derive benefits from free cash-flow. ${ }^{10}$

\section{B. Pricing of Bank Power Debt}

Since Proposition 2 shows that weak firms optimally choose exclusive bank debt finance, in the remainder of the paper discussion of weak firms is confined to those financing exclusively with BPD. We now solve for the price of BPD and the bank's optimal reorganization threshold $X_{b}$. The cash-flow to the bank in renegotiation states is equal to debt service, denoted by $\bar{s}(X)$, less renegotiation costs, if any:

$$
\begin{aligned}
\text { Cash-Flow to Bank } & =\bar{s}(X)-\delta[b-\bar{s}(X)]^{+} \\
& = \begin{cases}b & \text { for non-renegotiation states } \\
X-\delta[b-X] & \text { for renegotiation states }\end{cases}
\end{aligned}
$$

Letting the subscripts $\mathrm{L}$ and $\mathrm{H}$ denote the low and high EBIT regions, the general solution for the value of $\mathrm{BPD}$ is as follows:

$$
\begin{array}{lll}
B_{L}(X)=A_{1} X^{a}+A_{2} X^{z}+\frac{X(1+\delta)}{r-\mu}-\frac{\delta b}{r} & \forall X \in\left[X_{b}, X_{n}\right) \\
B_{H}(X)=A_{3} X^{a}+A_{4} X^{z}+\frac{b}{r} & \forall X \in\left[X_{n}, \infty\right) .
\end{array}
$$

Since the bank effectively chooses when to induce reorganization, we impose value matching and smooth pasting conditions for the bank debt value function, with $B$ pasting up smoothly to the function $L=(1-\alpha) V$ at $X_{b}$. Taking $X_{n}$ as given, for the moment, the unknowns for this problem are $\left(A_{1}, A_{2}, A_{3}, A_{4}, X_{b}\right)$ which are derived using the following boundary conditions:

$$
\begin{gathered}
B_{L}\left(X_{b}\right)=(1-\alpha) V\left(X_{b}\right), \\
\frac{\partial B_{L}\left(X_{b}\right)}{\partial X}=(1-\alpha) V^{\prime}\left(X_{b}\right), \\
B_{L}\left(X_{n}\right)=B_{H}\left(X_{n}\right) \\
\frac{\partial B_{L}\left(X_{n}\right)}{\partial X}=\frac{\partial B_{H}\left(X_{n}\right)}{\partial X} \\
\lim _{X \rightarrow \infty} B_{H}(X)=\frac{b}{r}
\end{gathered}
$$

\footnotetext{
${ }^{10}$ See Morellec (2002) for a recent survey and treatment of managerial discretion within a pricing framework.
} 
The solution is as follows:

$$
\begin{array}{rlrl}
B_{L}(X) & =\frac{X(1+\delta)}{r-\mu}-\frac{\delta b}{r}\left[1-\frac{1}{(1-a)}\left(\frac{X}{X_{b}}\right)^{a}\right] & \forall X \in\left[X_{b}, X_{n}\right) \\
B_{H}(X) & =\left[\frac{\delta b}{r(1-a)}\right]\left[\frac{X}{X_{b}}\right]^{a}-\left[\frac{(1+\delta) b}{r(1-a)}\right]\left[\frac{X}{X_{n}}\right]^{a}+\frac{b}{r} \quad \forall X \in\left[X_{n}, \infty\right) . \\
X_{b} & =\left[\frac{\delta}{\delta+\tau+\alpha(1-\tau)]}\right]\left(\frac{r-\mu}{r}\right)\left(\frac{a}{a-1}\right) b=\left[\frac{\delta}{\delta+\tau+\alpha(1-\tau)]}\right] X_{n}
\end{array}
$$

Lemma 4 follows from inspection of the equation for $X_{b}$ :

Lemma 4 For the Weak Firm with exclusive Bank Debt finance, a necessary and sufficient condition for reorganization is $\delta>0$.

Based on Lemma 1, the optimal renegotiation point for equity $\left(X_{n}\right)$ may be derived using the default rule for equity when the firm has financed exclusively with MD. This solution is provided below in (38), where the MD model is solved. Figure 2 graphs the Equity and Bank Power Debt value functions under positive renegotiation costs. Note that the Equity value function pastes smoothly to zero at $X_{n}$, while the BPD value function pastes smoothly to the reorganization value function $(L)$ at $X_{b}$.

\section{Valuation of Weak Firm}

Having characterized the debt service function for BPD we can now solve for the constituent pieces of levered firm value. It is easily verified that the sum of instantaneous cash flows to equity and bank debt in this case is:

$$
\text { Firm Cash Flow }=(1-\tau) X+\tau \bar{s}(X)-\delta[b-\bar{s}(X)]^{+}
$$

This implies the value of the levered firm can be expressed as the sum of the unlevered firm value, plus the value of the tax shield $(T B)$, less renegotiation costs $(N)$, less bankruptcy costs $(B C)$ :

$$
v(X)=V(X)+T B(X)-N(X)-B C(X)
$$

Before proceeding, the price of a particular primary claim will be of use for valuing a number of claims on the firm. Consider a primary claim paying $\$ 1$ at the first-passage time from above of 
the EBIT process $X$ to some threshold $X^{*}$. Based on (2), it may be verified that for $X \geq X^{*}$, this claim's value is:

$$
\text { Hitting Claim }=\left(\frac{X}{X^{*}}\right)^{a}
$$

The tax shield value is equal to the tax rate $(\tau)$ multiplied by the expected present value of future coupon payments. For the weak firm financed with bank debt exclusively, the value of coupons is equal to the value of BPD plus the value of renegotiation costs less the value of the claim to recoveries in reorganization. To determine the value of the recovery claim, the value of a hitting claim paying off at $X_{b}$ is multiplied by the bank's reorganization payoff, $L\left(X_{b}\right)$. Therefore, the tax shield value is:

$$
T B(X)=\tau\left[B(X)+N(X)-L\left(X_{b}\right)\left(\frac{X}{X_{b}}\right)^{a}\right] \text { for BPD. }
$$

For BPD the deadweight loss in the event of default is given by $\alpha V\left(X_{b}\right)$. Therefore, we have the following expression for bankruptcy costs:

$$
B C(X)=\alpha V\left(X_{b}\right)\left(\frac{X}{X_{b}}\right)^{a} \text { for } \mathrm{BPD}
$$

The value of renegotiation costs is derived in the appendix. With the terms in the levered firm value expression (13) in hand, the value of equity can be expressed as a residual based on (5). In the case of BPD, equity is worth zero for $X \leq X_{n}$, since it is pushed down to its reservation value in renegotiations. The following pricing equation holds on the interval $\left(X_{n}, \infty\right)$ :

$$
E(X)=V(X)-V\left(X_{b}\right)\left(\frac{X}{X_{b}}\right)^{a}-(1-\tau)\left[B(X)+N(X)-L\left(X_{b}\right)\left(\frac{X}{X_{b}}\right)^{a}\right] \text { for BPD. }
$$

Figure 3 depicts ex ante firm value for the weak firm under exclusive BPD finance, as is optimal. With positive $\delta$, the model yields an interior solution for the optimal BPD coupon. In the limit as $\delta$ approaches zero, the firm achieves first-best value by setting an arbitrarily high coupon.

\section{Strong Firm: Senior Bank Debt}

Having finished our analysis of the weak firm, the remainder of the paper considers optimal debt structure for the strong firm. Recall, the strong firm has full ex post bargaining power in renegotiations, with the corresponding debt obligation labeled Equity Power Debt (EPD). This section 
analyzes Senior EPD and the next analyzes Junior EPD. Anticipating, we will demonstrate that the strong firm finds it optimal to use a mixture of bank and market debt, with the bank placed senior.

For the purpose of generality, consider a priority structure that is described by the parameter $\eta \in(0,1]$, which represents the percentage of reorganization value $(L)$ paid to the bank, with $(1-\eta) L$ being paid to the bond market lenders. ${ }^{11}$ Priority structure influences the valuation of contingent claims on strong firms since in renegotiation equity makes take-it-or-leave-it offers, pushing the bank down to its reservation value. The bank's EBIT contingent reservation value is denoted $R$. For Senior Bank Debt under strict adherence to AP, the reservation value function is:

$$
\text { Bank Senior } \Rightarrow R(X)=\min \left\{\frac{b}{r}, L(X)\right\} \text {. }
$$

For the strong firm, the case of Senior Bank Debt is subsumed in the linear sharing rule, setting $\eta=1$. The reasoning is as follows. If there is no renegotiation, then the analysis of the strong firm issuing the pair $(b, c)$ is identical to that of exclusive MD finance with coupon $b+c$. If the pair $(b, c)$ is such that there is renegotiation, it must be the case that:

$$
R(X)=L(X)<\frac{b}{r}
$$

on any renegotiation region, otherwise the bank rejects any offer less than $b$. Therefore, setting $\eta=1$ produces the correct threat point, debt service, and claim valuations.

\section{A. Debt Service under Linear Sharing}

Equity's ex post problem involves choosing a stopping time $T \in \mathbf{T}$, as well as the instantaneous debt service paid the bank. Further, bank debt service in renegotiation states must be sufficient to induce acceptance by the bank. Again letting $B$ denote the bank debt value function, the debt service function must be chosen from the set $\mathbf{S}$ where:

$$
\mathbf{S} \equiv\{s: s \text { is piecewise right continuous and } s(X)<b \Rightarrow B(X) \geq R(X)\} .
$$

\footnotetext{
${ }^{11}$ We assume equity receives zero, although the model accomodates alternative assumptions.
} 
The equity value function is then given by: ${ }^{12}$

$$
E(X)=\sup _{s \in \mathbf{S}, T \in \mathbf{T}} \mathbf{E}_{0}\left[\int_{0}^{T} e^{-r t}\left[(1-\tau)\left(X_{t}-c-s\left(X_{t}\right)\right)-\delta\left(b-s\left(X_{t}\right)\right)^{+}\right] d t\right]
$$

The ex post incentive compatible (IC) strategic debt service function is denoted $\widehat{s}$. We now characterize the IC strategic debt service that obtains when the initial debt structure, as characterized by the triple $(b, c, \eta)$, is such that renegotiation occurs. Note that there exists a critical value $X_{\text {crit }}$ such that:

$$
R\left(X_{c r i t}\right) \equiv \frac{b}{r}
$$

Clearly, for any $X>X_{\text {crit }}$, an offer less than $b$ would be rejected by the bank. Consequently, there must exist an interval, $\left[X_{n}, \infty\right)$, such that no renegotiation occurs and $\widehat{s}(X)=b$. Further, since the instantaneous flow to equity is decreasing in $s$, the IC debt service entails $B(X)=R(X)$ on the renegotiation region. Based on (2), the function $B$ must satisfy the following ODE in non-reorganization states:

$$
\frac{1}{2} \sigma^{2} X^{2} B^{\prime \prime}(X)+\mu X B^{\prime}(X)-r B(X)+\widehat{s}(X)=0
$$

Substituting $R$ and its derivatives for $B$ implies that in the renegotiation region, strategic debt service is linear in $X$, taking the form:

$$
\widehat{s}(X)=\eta(1-\alpha)(1-\tau) X .
$$

Equation (24) is informative about the role of priority structure in the model. When the bank is placed high in the priority structure, the strategic default problem is mitigated since EPD debt service in renegotiation states is increasing in $\eta$. In fact, priority has a two-fold effect. It is shown below, in (28), that for a given $(b, c)$ pair, equity's renegotiation threshold $\left(X_{n}\right)$ is decreasing in $\eta$. In other words, higher values of $\eta$ induce equity to wait longer before entering into renegotiations, and to pay more to the bank in renegotiation states. By definition, the strong firm retains full $e x$ post bargaining power, in that it can make take-it-or-leave-it offers to the bank. Priority is simply a device for raising the bank's threat point. Finally, it should be noted that higher bankruptcy costs $(\alpha)$ erode the threat point of the bank in renegotiations, reducing strategic debt service.

\footnotetext{
${ }^{12}$ This assumes equity pays the renegotiation cost. The party literally paying this cost is immaterial, since the net payment to the bank is uniquely determined by the bank's reservation value function.
} 
To determine equity's optimal switch point for renegotiations $\left(X_{n}\right)$, consider starting at an arbitrarily high value of $X$ where the payment of $b$ is made. In choosing its switch point, equity finds the highest value of $X$ such that the offer given in (24) is accepted by the bank in the left neighborhood of $X_{n}$. Technically, this reduces the optimal renegotiation strategy to a smoothpasting problem.

Below, the subscripts $L$ and $H$ denote claim values for $X<X_{n}$ and $X \geq X_{n}$, respectively. Letting $X_{e}$ represent the equity's default threshold, derived below, the EPD value function is given by: ${ }^{13}$

$$
\begin{aligned}
B_{L}(X) & =\eta(1-\alpha) V(X) \quad \forall X \in\left[X_{e}, X_{n}\right) \\
B_{H}(X) & =A_{5} X^{a}+A_{6} X^{z}+\frac{b}{r} \forall X \in\left[X_{n}, \infty\right) .
\end{aligned}
$$

The unknowns for this problem are $\left(A_{5}, A_{6}, X_{n}\right)$, which are derived using the following boundary conditions, which represent value matching, smooth pasting and asymptotic conditions, respectively:

$$
\begin{gathered}
B_{H}\left(X_{n}\right)=\eta(1-\alpha) V\left(X_{n}\right), \\
\frac{\partial B_{H}\left(X_{n}\right)}{\partial X}=\frac{\eta(1-\alpha)(1-\tau)}{r-\mu} \\
\lim _{X \rightarrow \infty} B_{H}(X)=\frac{b}{r}
\end{gathered}
$$

These conditions yield the following bank debt values and renegotiation threshold for EPD:

$$
\begin{gathered}
B_{L}(X)=\eta(1-\alpha) V(X) \\
B_{H}(X)=\frac{b}{r}\left[1-\frac{1}{1-a}\left(\frac{X}{X_{n}}\right)^{a}\right] \\
X_{n}=\left(\frac{r-\mu}{r}\right)\left(\frac{a}{a-1}\right)\left[\frac{b}{\eta(1-\alpha)(1-\tau)}\right] .
\end{gathered}
$$

One might be tempted to conclude that the IC debt service entails entering renegotiations for all values of $X$ such that the expression given in (24) is less than $b$, in which case $\widehat{s}$ would be continuous in $X$. However, this debt service function does not belong to the feasible set $\mathbf{S}$ as defined in (20). In particular, the switch point under such a policy causes the value of the bank debt to fall below the reservation value in the left neighborhood of the proposed $X_{n}$, implying that renegotiation

\footnotetext{
${ }^{13}$ In the case of no default, the term $X_{e}$ is replaced with zero.
} 
offers would be rejected. Therefore, the IC debt service function must exhibit a jump at the point $X_{n}$. This is confirmed below for the optimal switch point given in (28):

$$
\lim _{X \uparrow X_{n}} \widehat{s}\left(X_{n}\right)=\left(\frac{r-\mu}{r}\right)\left(\frac{a}{a-1}\right) b<b .
$$

Figure 4 plots strategic debt service for the strong firm issuing Senior $\operatorname{EPD}(\eta=1)$. Here one can see the jump in debt service that must occur at $X_{n}$. Figure 5 plots the value functions for Senior EPD for alternative values of the bankruptcy cost parameter $(\alpha)$. The effect of increasing $\alpha$ is analogous to that of reducing $\eta$, which is not surprising in that higher values of $\alpha$ and lower values of $\eta$ both serve to lower the bank's threat point. Note that the EPD value functions paste smoothly to the bank's reservation value function at the respective $X_{n}$ thresholds, where $X_{n}$ is increasing in $\alpha$.

\section{B. Valuations under Linear Sharing}

The sum of instantaneous cash flows to equity, market debt, and bank debt is:

$$
\text { Firm Cash Flow }=(1-\tau) X+\tau[c+\widehat{s}(X)]-\delta[b-\widehat{s}(X)]^{+}
$$

This implies that the value of the levered firm can be expressed as in (13).

The value of the tax shield under EPD is equal to the tax rate $\tau$ multiplied by the expected present value of future coupon service paid to the bank and bond market lenders. This is equal to the value EPD plus MD less the value of creditors' claims to recoveries in default. Therefore, the tax shield value is:

$$
T B(X)=\tau\left[C(X)+B(X)-L\left(X_{e}\right)\left(\frac{X}{X_{e}}\right)^{a}\right] \text { for EPD. }
$$

We have the following expression for bankruptcy costs:

$$
B C(X)=\alpha V\left(X_{e}\right)\left(\frac{X}{X_{e}}\right)^{a} \text { for EPD. }
$$

The value function for market debt satisfies (2) with flow payment equal to $c$ on the non-default region. The boundary conditions are value matching at $X_{e}$, and an asymptotic condition:

$$
\begin{aligned}
C\left(X_{e}\right) & =(1-\eta)(1-\alpha) V\left(X_{e}\right), \\
\lim _{X \rightarrow \infty} C(X) & =\frac{c}{r} .
\end{aligned}
$$


The solution for the value of MD is given by:

$$
C(X)=\frac{c}{r}\left[1-\left(\frac{X}{X_{e}}\right)^{a}\right]+(1-\eta)(1-\alpha) V\left(X_{e}\right)\left(\frac{X}{X_{e}}\right)^{a} .
$$

Renegotiation costs for the strong firm are derived in the appendix. With each of the terms in the levered firm value expression (13) in hand, the value of equity can be expressed as a residual based on (5). In the case of EPD, the following valuation equation holds on the interval $\left[X_{e}, \infty\right)$ :

$$
E(X)=V(X)-V\left(X_{e}\right)\left(\frac{X}{X_{e}}\right)^{a}-(1-\tau)\left[B(X)+C(X)-L\left(X_{e}\right)\left(\frac{X}{X_{e}}\right)^{a}\right]-N(X)
$$

The remaining unknown for the case of EPD with linear sharing is the optimal default threshold, $X_{e}$, which is derived using the smooth pasting condition at default. The endogenous defaulttriggering EBIT level for the strong firm with the mixed debt pair $(b, c)$ and linear sharing in default is: ${ }^{14}$

$$
X_{e}(b, c)=\left(\frac{r-\mu}{r}\right)\left(\frac{a}{a-1}\right) \frac{\delta b+(1-\tau) c}{(1-\tau)[1-\eta(1-\alpha)(1-\tau-\delta)]}
$$

\section{Exclusive Market Debt Finance}

In order to contrast results on the optimal mix of Senior EPD and MD, consider first optimal debt structure for a firm constrained to issue MD exclusively. The analysis mirrors that in Leland (1994). Dropping terms in the firm value expression involving bank debt, we have:

$$
v\left(X_{0} ; 0, c\right)=V\left(X_{0}\right)+\frac{\tau c}{r}\left(1-\left(\frac{X_{0}}{X_{e}}\right)^{a}\right)-\alpha V\left(X_{e}\right)\left(\frac{X_{0}}{X_{e}}\right)^{a} .
$$

Expression (36) simplifies to:

$$
X_{e}(0, c)=\left(\frac{r-\mu}{r}\right)\left(\frac{a}{a-1}\right) c .
$$

The optimal coupon commitment satisfies the first-order condition $\partial v\left(X_{0} ; 0, c^{*}\right) / \partial c=0$ :

$$
c^{*}\left(X_{0}\right)=\left(\frac{r}{r-\mu}\right)\left(\frac{a-1}{a}\right)\left[\frac{\tau}{\tau-a(\tau+\alpha-\alpha \tau)}\right]^{(-1 / a)} X_{0}
$$

Substituting this expression back into the total firm value expression yields the ex ante value of an optimally levered firm financing with MD exclusively:

$$
v\left(X_{0} ; 0, c^{*}\right)=V\left(X_{0}\right)+\left(\frac{\tau X_{0}}{r-\mu}\right)\left[\frac{\tau}{\tau-a(\tau+\alpha-\alpha \tau)}\right]^{(-1 / a)}
$$

\footnotetext{
${ }^{14}$ This expression assumes $(b, c)$ entails renegotiation. If there is no renegotiation, default is trigged at $X_{e}(0, b+c)$.
} 
Figure 6 depicts the value of the levered firm financing exclusively with MD for alternative values of bankruptcy costs under the following baseline parameters:

$\begin{array}{cc}\text { Parameter } & \text { Value } \\ X_{0} & 20 \\ r & 6 \% \\ \mu & 1 \% \\ \sigma & 25 \% \\ \alpha & 50 \% \\ \tau & 20 \% \\ \delta & 0 \%\end{array}$

\section{Optimal Mix of Senior EPD and Market Debt}

In the absence of renegotiation costs, the model yields a tractable closed-form solution for the optimal mix of Senior EPD and Junior MD. Using the pricing formulas given above, the maximization problem for the firm at date zero may be stated as:

$$
\begin{gathered}
\max _{(b, c)} v\left(X_{0} ; b, c\right)=V\left(X_{0}\right)+\tau\left[C\left(X_{0}\right)+B\left(X_{0}\right)-L\left(X_{e}\right)\left(\frac{X_{0}}{X_{e}}\right)^{a}\right]-\alpha V\left(X_{e}\right)\left(\frac{X_{0}}{X_{e}}\right)^{a} \\
X_{e}(b, c)=\left(\frac{r-\mu}{r}\right)\left(\frac{a}{a-1}\right)\left(\frac{c}{1-(1-\alpha) 1-\tau)}\right)
\end{gathered}
$$

Rearranging terms, the maximand may be restated as:

$$
\max _{(b, c)} V\left(X_{0}\right)+\tau C\left(X_{0}\right)-(\tau+\alpha-\alpha \tau) V\left(X_{e}\right)\left(\frac{X_{0}}{X_{e}}\right)^{a}+\tau B\left(X_{0}\right)
$$

This reveals that the maximization problem is separable in $b$ and $c$, since the first three terms do not depend on $b$, while the last term does not depend on $c$.

The optimal EPD coupon maximizes the value of the bank debt. Therefore, the optimal debt mix entails issuing EPD up to the firm's bank debt capacity. The intuition for bank debt capacity in this setting is as follows. From the equation for the endogenous renegotiation threshold given in (28), it can be seen that $X_{n}$ is increasing in $b$. For a fixed initial EBIT level, low levels of $b$ are consistent with $X_{0}>X_{n}(b)$. However, for $b$ sufficiently high, the bank recognizes that equity will push it down to the reservation value $L\left(X_{0}\right)$ immediately. This implies that further increasing the 
promised coupon cannot raise the value of debt, since the reservation value is invariant to $b$. More formally, the bank debt capacity, $b^{\text {max }}$, satisfies:

$$
X_{n}\left(b^{\max }\right)=X_{0} \quad \Leftrightarrow \quad b^{\max }=\left(\frac{r}{r-\mu}\right)\left(\frac{a-1}{a}\right)(1-\alpha)(1-\tau) X_{0} .
$$

And we have shown:

$$
b^{*}=b^{\max }
$$

The first-order condition for $c$ yields:

$$
c^{*}\left(X_{0}\right)=(\tau+\alpha-\alpha \tau)\left(\frac{r}{r-\mu}\right)\left(\frac{a-1}{a}\right)\left[\frac{\tau}{\tau-a}\right]^{(-1 / a)} X_{0}
$$

A comparison of (46) with (39) reveals that the optimal MD coupon commitment is lower for the mixed debt firm. This is because under the mixed debt policy, the marginal bankruptcy cost of MD is higher, as is indicated by comparing the respective default thresholds given in (38) and (42).

Substituting yields the ex ante value of an optimally levered strong firm issuing a mix of Senior EPD and Junior MD:

$$
v\left(X_{0} ; b^{*}, c^{*}\right)=V\left(X_{0}\right)+\tau L\left(X_{0}\right)+\left(\frac{\tau X_{0}}{r-\mu}\right)(\tau+\alpha-\alpha \tau)\left(\frac{\tau}{\tau-a}\right)^{(-1 / a)}
$$

Equation (47) identifies the sources of value created by the mixed debt policy for the strong firm. Consider first the value of the optimally levered strong firm that is constrained to finance exclusively with bank debt, not having access to market debt. It is easily verified that this firm does not incur default costs and levers up to bank debt capacity. Firm value under pure EPD finance is given by:

$$
v\left(X_{0} ; b^{*}, 0\right)=V\left(X_{0}\right)+\tau L\left(X_{0}\right) .
$$

This is the same as the first two terms in (47), with the remaining term representing the value gained from issuing MD.

Figure 7 plots levered firm value as a function of the promised coupons on Senior EPD and Junior MD for the baseline parameters. The hollow region represents $(b, c)$ pairs such that there is no renegotiation region. Note that a necessary condition for a renegotiation equilibrium to make economic sense is:

$$
X_{e}(b, c)<X_{n}(b, c)
$$


This condition is not satisfied when $c$ and/or $\delta$ are high relative to $b$. The analysis of $(b, c)$ pairs such that no renegotiation region exists is subsumed in the analysis of the firm financing exclusively with MD. Figure 7 depicts the interior solution for $c^{*}$ and the debt capacity condition for $b^{*}$.

The model generates quantitative estimates of the optimal debt mix that are consistent with the empirical evidence. In particular, the total value of the optimally levered firm is 360.66 , with the bank debt value equal to 160.00 and the market debt value equal to 70.10. Therefore, the market debt percentage of total debt value is equal to $30.5 \%$. This is close to the mean (median) market debt percentage of 34\% (40\%) documented by Houston and James (1996). Johnson (1997) presents higher estimates of the weight on market debt, but his sample excludes short-term debt, which probably results in understating weight on bank debt.

The optimal leverage ratio, computed as total debt value divided by total firm value, is equal to $63.8 \%$, which is in excess of those generally observed. A number of factors could account for this finding. First, the model rules out managerial discretion regarding leverage choice. Grossman and Hart (1982), Jensen (1986), Zwiebel (1996), and Morellec (2002) cite preservation of free cash-flow by self-interested managers as a potential explanation for debt conservatism. Second, tractability demands that we treat the corporate tax schedule as linear, while Graham (2000) finds that various features of the tax code, such as loss-limits and carry-forward rules, create non-linearities which reduce the value of the debt tax shield.

The model allows us to quantify the benefit accruing to the firm from being able to access both bank and market debt. The first line below reports the ex ante firm value attained when the strong firm may mix Senior EPD and Junior MD. The second and third lines report valuations under exclusive MD and EPD finance, respectively:

$$
\begin{aligned}
v\left(b^{*}, c^{*}\right) & =360.66 \\
v\left(0, c^{*}\right) & =328.65 \\
v\left(b^{*}, 0\right) & =352.00
\end{aligned}
$$

The value increase for a strong firm that is able to issue market debt after having been constrained to issue bank debt (EPD) exclusively is $9.7 \%$. The value increase for a strong firm that is able to issue senior bank debt after having been constrained to issue market debt exclusively is $2.5 \%$. 
Figure 8 shows the effect of the introduction of renegotiation costs on the optimal mix of Senior EPD and Junior MD. The existence of renegotiation costs creates a unique interior solution for the optimal debt mix, in contrast to the result depicted in Figure 7 where $\delta=0$ creates indeterminacy regarding the optimal bank debt coupon commitment.

\section{Strong Firm: Junior Bank Debt}

Under Junior EPD finance, equity again makes take-it-or-leave-it offers, pushing the bank down to its reservation value function. The linear sharing rule discussed above does not subsume the case of Junior EPD since the reservation value of the bank in this case is determined by:

$$
\text { Bank Junior } \Rightarrow R(X)=\min \left\{\frac{b}{r}, \max \left\{0, L(X)-\frac{c}{r}\right\}\right\} \text {. }
$$

In this section we characterize equilibria for Junior EPD under the assumption that there is a region of debt renegotiation. For any pair $(b, c)$ such that there is no renegotiation region, the analysis is identical to that under exclusive MD finance with promised coupon $\bar{c}=b+c$.

\section{A. Debt Service under Junior EPD}

In any renegotiation equilibrium under Junior EPD, there are three distinct debt service regions. For high values of $X$ the contractual debt service of $b$ is paid. In some left neighborhood of $X_{n}$, the bank's reservation value is given by $L(X)-c / r$, and strategic debt service pins $B$ to this value. Finally, when $L(X)-c / r \leq 0$ the bank's reservation value is zero and debt service is equal to zero.

Consider first the strategic debt service flows, denoted $\widehat{s}(X)$, when the bank's reservation value is equal to $L(X)-c$. Since equity pins the bank to its reservation value, we have:

$$
B(X)=R(X)=\frac{(1-\alpha)(1-\tau) X}{r-\mu}-\frac{c}{r} .
$$

Substituting in $R$ and its derivatives into (23) implies that in this region, strategic debt service is equal to:

$$
\widehat{s}(x)=(1-\alpha)(1-\tau) X-c
$$

Comparing (24) with (53) we see that for the strong firm, placing the bank junior results in a downward shift in the EPD debt service by the amount $c$. Given that the bank debt value function 
goes to zero for sufficiently low values of $X$, it is necessarily the case that debt service is negative on some part of the renegotiation region. Intuitively, the bank is willing to infuse cash on some interval in order to preserve the value of its option on positive debt service in good states.

Finally, the Junior EPD reservation value function hits zero at the threshold:

$$
X_{\ell}=\left(\frac{r-\mu}{r}\right) \frac{c}{(1-\alpha)(1-\tau)} .
$$

Therefore, on the interval $\left[X_{e}, X_{\ell}\right)$ strategic debt service is zero. Summarizing, strategic debt service under Junior EPD is given by:

$$
\widehat{s}(X)=\left\{\begin{array}{ll}
b & \forall X \in\left[X_{n}, \infty\right) \\
(1-\alpha)(1-\tau) X-c & \forall X \in\left[X_{\ell}, X_{n}\right) \\
0 & \forall X \in\left[X_{e}, X_{\ell}\right)
\end{array} .\right.
$$

Strategic debt service for Junior EPD is depicted in Figure 9. Debt service is negative in some right neighborhood of $X_{\ell}$, and we confirm below in (60) that the IC debt service function must be discontinuous at the point $X_{n}$.

The following Lemma follows from the debt service described above:

Lemma 5 For the Strong Firm issuing Junior Bank Debt, in any equilibrium with renegotiation, default must occur in the low region. That is:

$$
X_{e}(b, c)<X_{\ell}(b, c)
$$

Proof. Follows from the fact that cash-flow to equity is strictly positive on the region $\left[X_{\ell}, X_{n}\right)$, implying default is not optimal on this interval.

Corollary 6 For the Strong Firm issuing Junior Bank Debt, in any equilibrium with renegotiation, the Market Debt lenders collect all reorganization value.

Proof. Follows from $X_{e}<X_{\ell} \Longrightarrow L\left(X_{e}\right)<\frac{c}{r}$.

To determine the optimal switch point for initiating debt renegotiations $\left(X_{n}\right)$, consider starting out at an arbitrarily high value of $X$ where payment $b$ is made. In choosing its renegotiation threshold, the firm finds the highest possible value of $X$ such that the offer given in (55) is accepted 
by the bank in the left neighborhood of $X_{n}$ under rational expectations. Technically, this reduces the optimal renegotiation strategy to a smooth-pasting problem.

The Junior EPD debt value function is given by:

$$
\begin{aligned}
B_{L}(X) & =0 & & \forall X \in\left[X_{e}, X_{\ell}\right) \\
B_{M}(X) & =(1-\alpha) V(X)-\frac{c}{r} & & \forall X \in\left[X_{\ell}, X_{n}\right) \\
B_{H}(X) & =A_{7} X^{a}+A_{8} X^{z}+\frac{b}{r} & & \forall X \in\left[X_{n}, \infty\right)
\end{aligned}
$$

The remaining unknowns for this problem are $\left(A_{7}, A_{8}, X_{n}\right)$, which are derived using the following boundary conditions, which represent value matching, smooth pasting, and asymptotic conditions, respectively:

$$
\begin{gathered}
B_{H}\left(X_{n}\right)=(1-\alpha) V(X)-\frac{c}{r}, \\
\frac{\partial B_{H}\left(X_{n}\right)}{\partial X}=\frac{(1-\alpha)(1-\tau)}{r-\mu}, \\
\lim _{X \rightarrow \infty} B_{H}(X)=\frac{b}{r} .
\end{gathered}
$$

This yields the following bank debt value and renegotiation threshold: ${ }^{15}$

$$
\begin{gathered}
B_{H}(X)=\frac{b}{r}\left[1-\left(\frac{1}{1-a}\right)\left(\frac{X}{X_{n}}\right)^{a}\right]-\frac{c}{r}\left(\frac{1}{1-a}\right)\left(\frac{X}{X_{n}}\right)^{a} \\
X_{n}=\left(\frac{r-\mu}{r}\right)\left(\frac{a}{a-1}\right)\left[\frac{b+c}{(1-\alpha)(1-\tau)}\right] .
\end{gathered}
$$

The IC strategic debt service exhibits a jump at the optimal switch point given in (59), with:

$$
\lim _{X \uparrow X_{n}} \widehat{s}\left(X_{n}\right)=\left(\frac{r-\mu}{r}\right)\left(\frac{a}{a-1}\right)(b+c)-c<b .
$$

Note that the incentive compatible switch point for renegotiation under Junior EPD is identical to that under a Senior EPD bond with coupon $\bar{b}=b+c$. Thus, for any given pair $(b, c)$ renegotiation occurs at a higher EBIT level under Junior EPD than under Senior EPD. This is because placing the bank junior erodes its threat point in renegotiations.

Figure 10 plots the value functions for Junior EPD for alternative values of the bankruptcy cost parameter $(\alpha)$. The figure is identical to Figure 5 for Senior EPD, with the notable exception that placing the bank junior shifts the reservation value function right.

\footnotetext{
${ }^{15}$ In order for the posited equilibrium to be valid, it must be the case that $X_{\ell}<X_{n}$. A sufficient condition is $c<-a b$.
} 


\section{B. Valuations for Junior Equity Power Debt}

Under Junior EPD, the valuation formulas for the tax shield and bankruptcy costs are as given in (31) and (32), respectively. Equity is once again valued as the residual of firm value over EPD and MD. The valuation formula for Junior EPD is given above. In light of Corollary 6, we know that the MD lenders recover all reorganization value in default. Therefore, the MD value function changes to:

$$
C(X)=\frac{c}{r}\left[1-\left(\frac{X}{X_{e}}\right)^{a}\right]+(1-\alpha) V\left(X_{e}\right)\left(\frac{X}{X_{e}}\right)^{a}
$$

Application of the smooth pasting condition indicates that equity's endogenous default threshold under the mixed debt pair $(b, c)$ with the bank placed junior, is identical to that chosen by equity when the firm is financed exclusively with market debt carrying the same MD coupon $c$. This solution is given in (38).

\section{Optimal Mix of Junior EPD and Market Debt}

Based on the pricing formulas given above, the maximand for the firm as given in (41) may be restated as:

$$
\max _{(b, c)} v\left(X_{0} ; b, c\right)=V\left(X_{0}\right)+\frac{\tau c}{r}\left[1-\left(\frac{X_{0}}{X_{e}}\right)^{a}\right]-\alpha V\left(X_{e}\right)\left(\frac{X_{0}}{X_{e}}\right)^{a}+\tau B\left(X_{0} ; b, c\right)
$$

Note that the problem for Junior EPD is not separable in $(b, c)$ as was the case under Senior EPD. However, the optimal debt structure can be derived analytically using a two-step procedure. We

first solve for the optimal Junior EPD coupon commitment for an arbitrary $c$. We then solve a maximization problem over $c$.

Pick an arbitrary $c>0$. Note that each of the first three terms in the maximand is independent of $b$. Therefore, it must be the case that:

$$
b^{*}(c) \in \arg \max _{b} B\left(X_{0} ; b, c\right)
$$

Clearly, the optimal Junior EPD coupon commitment, given $c$, entails the firm being at its being debt capacity. Therefore:

$$
X_{n}\left[b^{*}(c), c\right]=X_{0} \Leftrightarrow b^{*}(c)=\left(\frac{r}{r-\mu}\right)\left(\frac{a-1}{a}\right)(1-\alpha)(1-\tau) X_{0}-c .
$$


Since the optimal EPD coupon commitment entails being at debt capacity, it follows that:

$$
B\left[X_{0} ; b^{*}(c), c\right]=(1-\alpha) V\left(X_{0}\right)-\frac{c}{r}
$$

Substituting (65) into (62) yields the following objective function in $c$ :

$$
\max _{c}[1+\tau(1-\alpha)] V\left(X_{0}\right)-\left(\frac{\tau c}{r}+\alpha V\left(X_{e}\right)\right)\left(\frac{X_{0}}{X_{e}}\right)^{a}
$$

The objective function is strictly declining in c, implying the following Proposition:

Proposition 7 If the Strong Firm is constrained to issuing bona fide Junior Bank Debt, it is optimal to choose the minimal Market Debt coupon and set:

$$
b^{*}=\left(\frac{r}{r-\mu}\right)\left(\frac{a-1}{a}\right)(1-\alpha)(1-\tau) X_{0}
$$

Intuitively, for Junior EPD, the tax shield attributable to bank debt is equal to $\tau B$. Therefore, in addition to bankruptcy costs, there is a large indirect tax shield cost associated with MD issuance when the bank is placed junior, since MD issuance directly reduces bank debt capacity. This cost swamps the direct tax shield benefit provided by the MD. This result is confirmed in Figure 11, which depicts levered firm value for varying amounts of Junior EPD and Senior MD. Note that firm value declines monotonically in $c$, while it increases in value up to the bank debt capacity.

We then have the following Proposition on priority.

Proposition 8 For the Strong Firm, Senior Bank Debt dominates Junior Bank Debt.

Proof. Bona fide Junior EPD is strictly dominated by pure EPD finance. Under pure EPD finance the firm does not incur default costs and levers up to bank debt capacity. Firm value is then given by $v\left(X_{0} ; b^{*}, 0\right)=V\left(X_{0}\right)+\tau L\left(X_{0}\right)$. This value is strictly less than that for the optimally levered strong firm using a mix of Senior EPD and Junior MD, as presented in (47).

This proposition is confirmed in our numerical analyses. Comparison of Figures 7 and 11 reveals that for our baseline parameters, the optimally levered firm issuing bona fide Junior EPD is valued at 352.01, whereas the optimally levered firm issuing a mix of Senior EPD and MD achieves a value of 360.66 , representing a $2.5 \%$ value differential. 


\section{Alternative Sharing Rules}

Above it was assumed that AP is obeyed. However, deviations from AP are common in Chapter 11 reorganizations. This is due to the fact that junior claimants have power to delay resolution and destroy value. In particular, in order for a reorganization to be approved, a majority in number and two-thirds by amount of each creditor class must vote in favor of the plan. Therefore, one may prefer to think of the firm as exercising imperfect control over the division of reorganization value through its contractual specification of priority.

It has been shown that it is optimal for the strong firm to place the bank senior, i.e. set $\eta=1$. With deviations from AP that are rationally anticipated by all agents, the firm is effectively constrained to choose $\eta$ from a subset of the interval $(0,1]$. For instance, even if the debt contracts specify that the bank is "senior," the bank may receive less than 100 percent of reorganization value due to hold-up problems in Chapter 11. This reduces ex ante firm value as the threat point of the bank in renegotiations is eroded.

Using the baseline parameters, suppose first that, as is optimal, the firm can commit to placing the bank senior in priority, setting $\eta=1$. Figure 7 shows that the optimally levered firm is valued at 360.66. Figures 12 and 13 depict levered firm values under two deviations from AP. In Figure 12, Junior MD lenders are able to extract 25 percent of reorganization value from the bank, implying $\eta=.75$. In Figure 13, the Junior MD lenders are able to extract 50 percent of reorganization value from the bank, implying $\eta=.50$. Firm valuations are given below:

$$
\begin{aligned}
& \eta=1.00 \Longrightarrow v\left(b^{*}, c^{*}\right)=360.66 \\
& \eta=0.75 \Longrightarrow v\left(b^{*}, c^{*}\right)=355.37 \\
& \eta=0.50 \Longrightarrow v\left(b^{*}, c^{*}\right)=350.36 .
\end{aligned}
$$

This analysis indicates that the ex ante value losses from deviations from AP across creditor classes are non-trivial. In percentage terms, the value loss from the deviation from AP is equal to $1.47 \%$ and $2.86 \%$ for $\eta=.75$ and $\eta=.50$, respectively.

Welch (1997) argues that tough banks create value by mitigating influence costs. Our results suggest an alternative reputational motive for banks to be tough in bargaining over reorganization value. In our model, banks that are able to extract more value in reorganization than their 
competitors are able to increase ex ante value for strong firms. This is because tough banks have high reservation values, implying that strategic debt service and tax shield values are higher when these banks are relied upon for soft debt.

\section{Conclusions}

Using an asset-pricing framework, this paper demonstrates that the traditional tax shield-bankruptcy cost tradeoff theory is sufficient to explain many stylized facts regarding corporate debt structure. The optimal debt structure for weak firms entails financing exclusively with bank debt. Strong firms optimally use mix of bank and market debt, with the bank senior. In addition to these qualitative predictions, the model generates quantitative estimates of the optimal debt mix that are consistent with existing empirical studies. However, empirically observed leverage ratios fall short of those predicted by the model. Therefore, our results contribute to the "debt conservatism" puzzle, as discussed in Graham (2000). Finally, adherence to AP is optimal in our model, and we quantify non-trivial costs of deviations from AP across creditor classes.

The assumption of consol bond finance precludes discussion of optimal maturity structure, suggesting a natural direction for future research. However, given the underlying similarity between our model and the discrete-time models presented by Diamond (1993b) and Berglöf and von Thadden (1994), there is good reason to believe that such an extension would generate results consistent with the stylized facts. In particular, given that the three models share the objective of toughening the bank, it is likely that our model will share their prediction that short maturity bank debt is optimal.

It should also be noted that nothing in our analysis precludes alternative theories regarding the role of bank debt. Rather, the rich set of predictions generated by application of continuoustime methods to the traditional tax shield-bankruptcy cost tradeoff theory suggest that further application of structural pricing models to banking problems will prove fruitful. 


\section{Appendix: Renegotiation Costs}

1. Renegotiation costs for the weak firm.

The negotiation cost function satisfies (2), with $\delta[b-s(X)]$ representing the flow term in the renegotiation region, while there is zero flow cost for $X \geq X_{n}$. The following value matching, smooth pasting, and asymptotic boundary conditions, are exploited:

$$
\begin{aligned}
N_{L}\left(X_{b}\right) & =0, \\
N_{L}\left(X_{n}\right) & =N_{H}\left(X_{n}\right), \\
\frac{\partial N_{L}\left(X_{n}\right)}{\partial X} & =\frac{\partial N_{H}\left(X_{n}\right)}{\partial X}, \\
\lim _{X \rightarrow \infty} N_{H}(X) & =0 .
\end{aligned}
$$

For BPD the solution for the renegotiation cost function is:

$$
\begin{gathered}
N_{L}(X)=\delta \frac{b}{r}\left[1-\left(1-\left(\frac{a}{a-z}\right)\left(\frac{X_{b}}{X_{n}}\right)^{z}\right)\left(\frac{X}{X_{b}}\right)^{a}-\left(\frac{a}{a-z}\right)\left(\frac{X}{X_{n}}\right)^{z}\right] \\
-\delta\left(\frac{1}{r-\mu}\right)\left[X-\left(X_{b}-\left(\frac{a-1}{a-z}\right) X_{n}\left(\frac{X_{b}}{X_{n}}\right)^{z}\right)\left(\frac{X}{X_{b}}\right)^{a}-\left(\frac{a-1}{a-z}\right) X_{n}\left(\frac{X}{X_{n}}\right)^{z}\right] \\
N_{H}(X)=\delta \frac{b}{r}\left[\left(\left(\frac{a}{a-z}\right)\left(\frac{X_{b}}{X_{n}}\right)^{z}-1\right)\left(\frac{X}{X_{b}}\right)^{a}-\left(\frac{z}{a-z}\right)\left(\frac{X}{X_{n}}\right)^{a}\right] \\
+\delta\left(\frac{1}{r-\mu}\right)\left[\left(X_{b}-\left(\frac{a-1}{a-z}\right) X_{n}\left(\frac{X_{b}}{X_{n}}\right)^{z}\right)\left(\frac{X}{X_{b}}\right)^{a}-\left(\frac{1-z}{a-z}\right) X_{n}\left(\frac{X}{X_{n}}\right)^{a}\right]
\end{gathered}
$$

2. Renegotiation costs for the strong firm.

The negotiation cost function satisfies $(2)$, with $\delta[b-\widehat{s}(X)]$ representing the flow term in the renegotiation region, while there is zero flow cost for $X \geq X_{n}$. The following boundary conditions pin down the solution:

$$
\begin{aligned}
N_{L}\left(X_{e}\right) & =0, \\
N_{L}\left(X_{n}\right) & =N_{H}\left(X_{n}\right), \\
\frac{\partial N_{L}\left(X_{n}\right)}{\partial X} & =\frac{\partial N_{H}\left(X_{n}\right)}{\partial X}, \\
\lim _{X \rightarrow \infty} N(X) & =0 .
\end{aligned}
$$

For EPD, the solution for the renegotiation cost function is:

$$
N_{L}(X)=\delta \frac{b}{r}\left[1-\left(1-\left(\frac{a}{a-z}\right)\left(\frac{X_{e}}{X_{n}}\right)^{z}\right)\left(\frac{X}{X_{e}}\right)^{a}-\left(\frac{a}{a-z}\right)\left(\frac{X}{X_{n}}\right)^{z}\right]
$$




$$
\begin{gathered}
-\delta\left(\frac{\eta(1-\alpha)(1-\tau)}{r-\mu}\right)\left[X-\left(X_{e}-\left(\frac{a-1}{a-z}\right) X_{n}\left(\frac{X_{e}}{X_{n}}\right)^{z}\right)\left(\frac{X}{X_{e}}\right)^{a}-\left(\frac{a-1}{a-z}\right) X_{n}\left(\frac{X}{X_{n}}\right)^{z}\right] \\
N_{H}(X)=\delta \frac{b}{r}\left[\left(\left(\frac{a}{a-z}\right)\left(\frac{X_{e}}{X_{n}}\right)^{z}-1\right)\left(\frac{X}{X_{e}}\right)^{a}-\left(\frac{z}{a-z}\right)\left(\frac{X}{X_{n}}\right)^{a}\right] \\
+\delta\left(\frac{\eta(1-\alpha)(1-\tau)}{r-\mu}\right)\left[\left(X_{e}-\left(\frac{a-1}{a-z}\right) X_{n}\left(\frac{X_{e}}{X_{n}}\right)^{z}\right)\left(\frac{X}{X_{e}}\right)^{a}-\left(\frac{1-z}{a-z}\right) X_{n}\left(\frac{X}{X_{n}}\right)^{a}\right]
\end{gathered}
$$




\section{References}

Anderson, Ron W. and Suresh M. Sundaresan, 1996, The design and valuation of debt contracts, Review of Financial Studies 9, 37-68.

Asquith, Paul, Robert Gertner, and David Scharfstein, 1994, The anatomy of financial distress: An examination of junk bond issuers, Quarterly Journal Economics 109, 625-658.

Bebchuk, Lucian Arye, 2002, Ex ante costs of violating absolute priority in bankruptcy, Journal of Finance, 57(1), 445-60.

Berglöf, Erik, and von Thadden, Ernst-Ludwig, 1994, Short-term versus long-term interests: Capital structure with multiple investors, Quarterly Journal Economics 109, 1055-1084.

Berlin, Mitchell and Jan Loeys, 1988, Bond covenants and delegated monitoring, Journal of Finance 43, $397-412$.

Bolton, Patrick, and Xavier Freixas, 2000, Equity, bonds, and bank debt: Capital structure and financial market equilibrium under asymmetric information, Journal of Political Economy 108, 324-342.

Bolton, Patrick, and Scharfstein, David S., 1996, Optimal debt structure and the number of creditors, Journal Political Economics 104, 1-25.

Bulow, Jeremy, Lawrence Summers and Victoria Summers, 1990, Distinguishing Debt from Equity in the Junk Bond Era, in : Debt, Taxes, and Corporate Restructuring (John Shoven and Joel Waldfogel, Eds.). Brookings Institution.

Carey, Mark, 1995, Are bank loans mispriced? Mimeo, Board of Governors of the Federal Reserve System.

Chemmanur, Thomas J. and Paolo Fulghieri, 1994, Reputation, renegotiation, and the choice between bank loans and publicly traded debt, Review of Financial Studies 7, 475-506.

Denis, David J. and Vassil T. Mihov, 2002, The choice among bank debt, non-bank private debt, and public debt: Evidence from new corporate borrowings, forthcoming in the Journal of Financial Economics.

Diamond, Douglas W., 1989, Reputation acquisition in debt markets, Journal of Political Economy, 97(4). 
Diamond, Douglas W., 1991, Monitoring and reputation: The choice between bank loans and directly placed debt, Journal of Political Economy 99, 688-721.

Diamond, Douglas W., 1993a, Seniority and maturity of debt contracts, Journal of Financial Economics $33,341-368$.

Diamond, Douglas W., 1993b, Bank loan maturity and priority when borrowers can refinance, in: Capital Markets and Financial Intermediation (Colin Mayer and Xavier Vives, Eds.). Cambridge University Press.

Fama, Eugene, 1985, What's different about banks?, Journal of Monetary Economics 15, 29-37.

Fama, Eugene, 1990, Contract costs and financing decisions, Journal of Business 63, 71-92.

Fan, Hua, and Suresh M. Sundaresan, 2000, Debt valuation, renegotiation, and optimal dividend policy, Review of Financial Studies 13, 1057-1099.

Franks, Julian, and Walter N. Torous, 1989, An empirical investigation of U.S. firms in reorganization, Journal of Finance 44, 747-769.

Franks, Julian, and Walter N. Torous, 1994, A comparison of financial recontracting in distressed exchanges and chapter 11 reorganizations, Journal of Financial Economics 35, 349-370.

Gertner, Robert and David Scharfstein, 1991, A theory of workouts and the effect of reorganization law, Journal of Finance 46, 1189-1122.

Gorton, Gary and James Kahn, 2000, The design of bank loan contracts, Review of Financial Studies 13(2), 331-364.

Graham, John R., 2000, How big are the tax benefits of debt, Journal of Finance 55, 1901-1941.

Grossman, Sanford and Oliver Hart, 1982, Corporate financial structure and managerial incentives, in The Economics of Information and Uncertainty (J. McCall, ed.). Chicago University Press.

Hart, Oliver, 1993, Theories of optimal capital structure: a managerial discretion perspective, in The Deal Decade: What Takeovers and Leveraged Buyouts Mean for Corporate Governance (Margaret Blair, ed.). Brookings Institution.

Hart, Oliver and John H. Moore, 1995, Debt and seniority: An analysis of the role of hard claims in constraining management, American Economic Review 85, 567-585 
Hart, Oliver and John H. Moore, 1998, Default and renegotiation: A dynamic model of debt, Quarterly Journal of Economics 103, 1-41.

Hege, Ulrich and Pierre Mella-Barral, 2000, Bargaining power and optimal leverage, Finance, 21, 85101.

Hege, Ulrich and Pierre Mella-Barral, 2002, Repeated dilution of diffusely held debt, mimeo.

Houston, Joel and Christopher James, 1996, Bank information monopolies and the mix of private and public debt claims, Journal of Finance 51, 1863-1889.

Jensen, Michael, 1986, Agency costs of free cash flow, corporate finance, and takeovers, American Economic Review, 76(2), 323-9.

Johnson, Shane, 1997, An empirical analysis of the determinants of corporate debt ownership structure, Journal of Financial and Quantitative Analysis, 32(1), 47-69.

Krishnaswami, Sudha, Paul Spindt, and Venkat Subramaniam, 1999, Journal of Financial Economics $51,407-434$.

Leland, Hayne E., 1994, Corporate debt value, bond covenants and optimal capital structure, Journal of Finance 49, 1213-252.

Mella-Barral, Pierre, and William Perraudin, 1997, Strategic debt service, Journal of Finance 52, 531556.

Morellec, Erwan, 2002, Can managerial discretion explain observed leverage ratios?, forthcoming in Review of Financial Studies.

Park, Cheol, 2000, Monitoring and structure of debt contracts, Journal of Finance 55, 2157-2195.

Rajan, Raghuram G., 1992, Insiders and outsiders: The choice between informed and arm's length debt, Journal of Finance 47, 1367-1400.

Schwartz, Alan, 1997, Priority contracts and priority in bankruptcy, Cornell Law Review 82, 1396-1435.

Scott, James A., Jr., 1977, Bankruptcy, secured debt, and optimal capital structure, Journal of Finance $32,1-19$.

Smith, Clifford W., Jr., and Jerold B. Warner, 1979, Bankruptcy, secured debt, and optimal capital structure: Comment, Journal of Finance 34, 247-251. 
Sundaresan, Suresh, 2000, Continuous-time methods in finance: A review and an assessment, Journal of Finance, 55, 1569-1622.

Weiss, Lawrence A., Bankruptcy resolution: Direct costs and violation of priority of claims, Journal of Financial Economics, 13, 137-151.

Welch, Ivo, 1997, Why is bank debt senior? A theory of asymmetry and claim priority based on influence costs, Review of Financial Studies 10, 1203-1236.

Zwiebel, Jeffrey, 1996, Dynamic capital structure under managerial entrenchment, American Economic Review, 86(5), 1197-1215. 


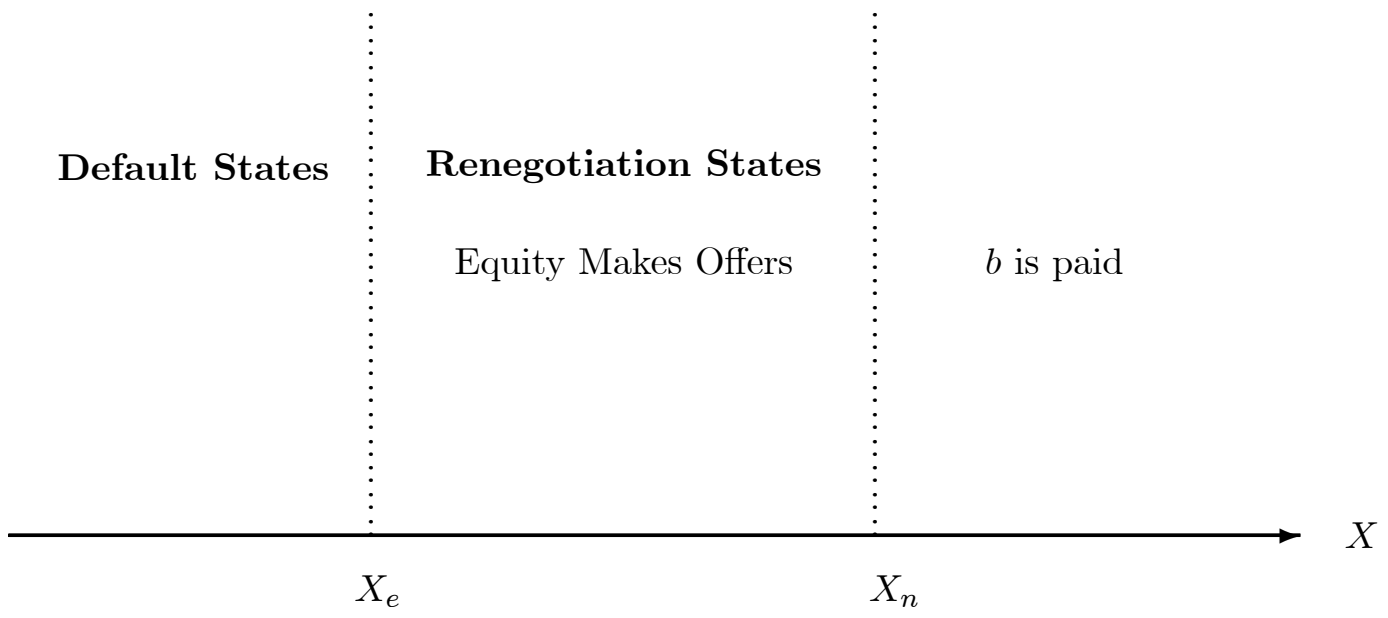




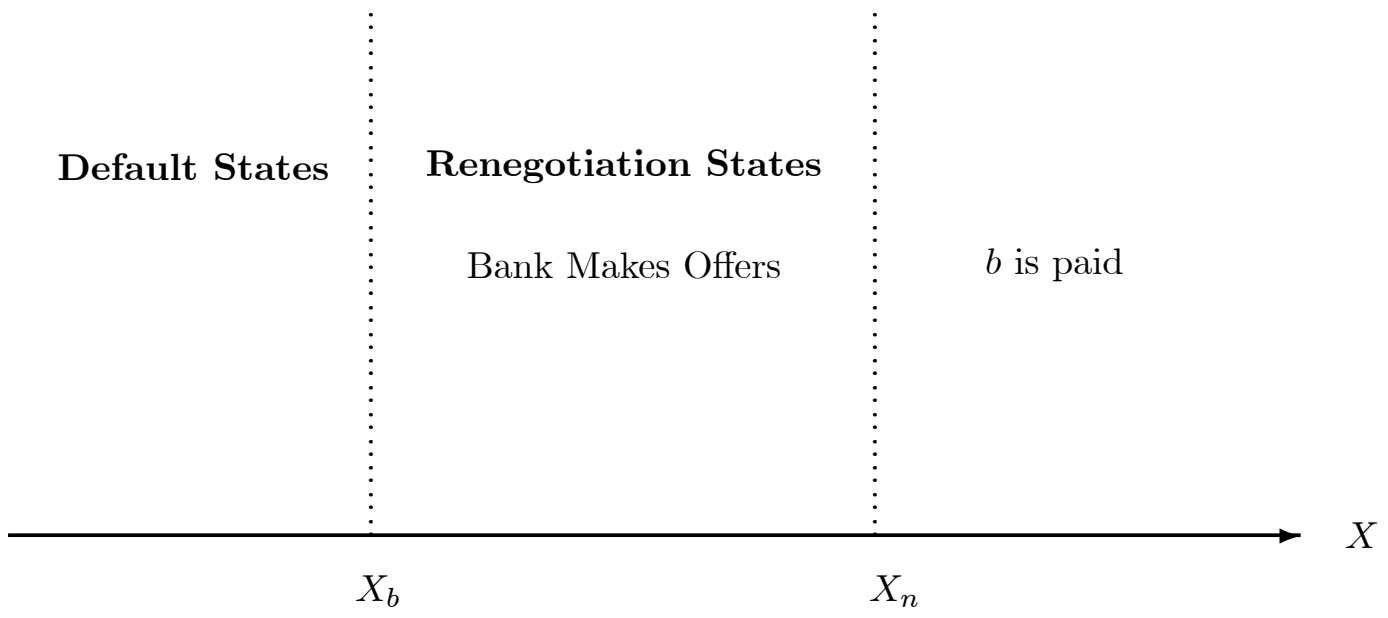




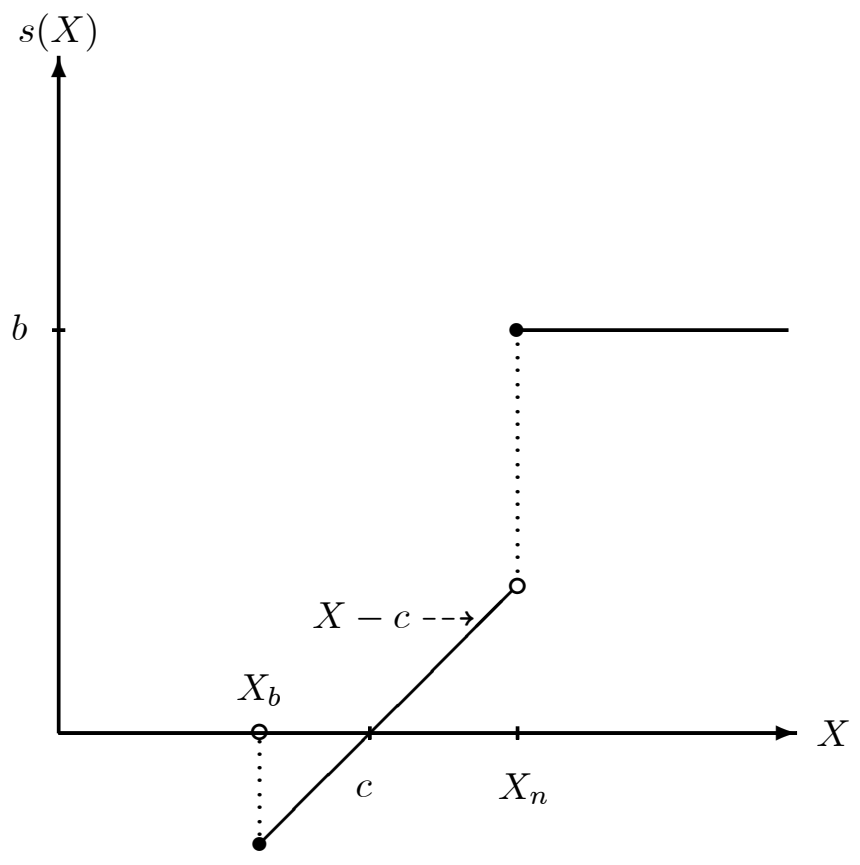

Figure 1: Strategic debt service $s(X)$ as a function of EBIT $X$ in case of Bank Power Debt $B$ with promised coupon $b$. It is assumed that there is Market Debt $(c>0)$, but no negotiation $\operatorname{costs}(\delta=0)$. 


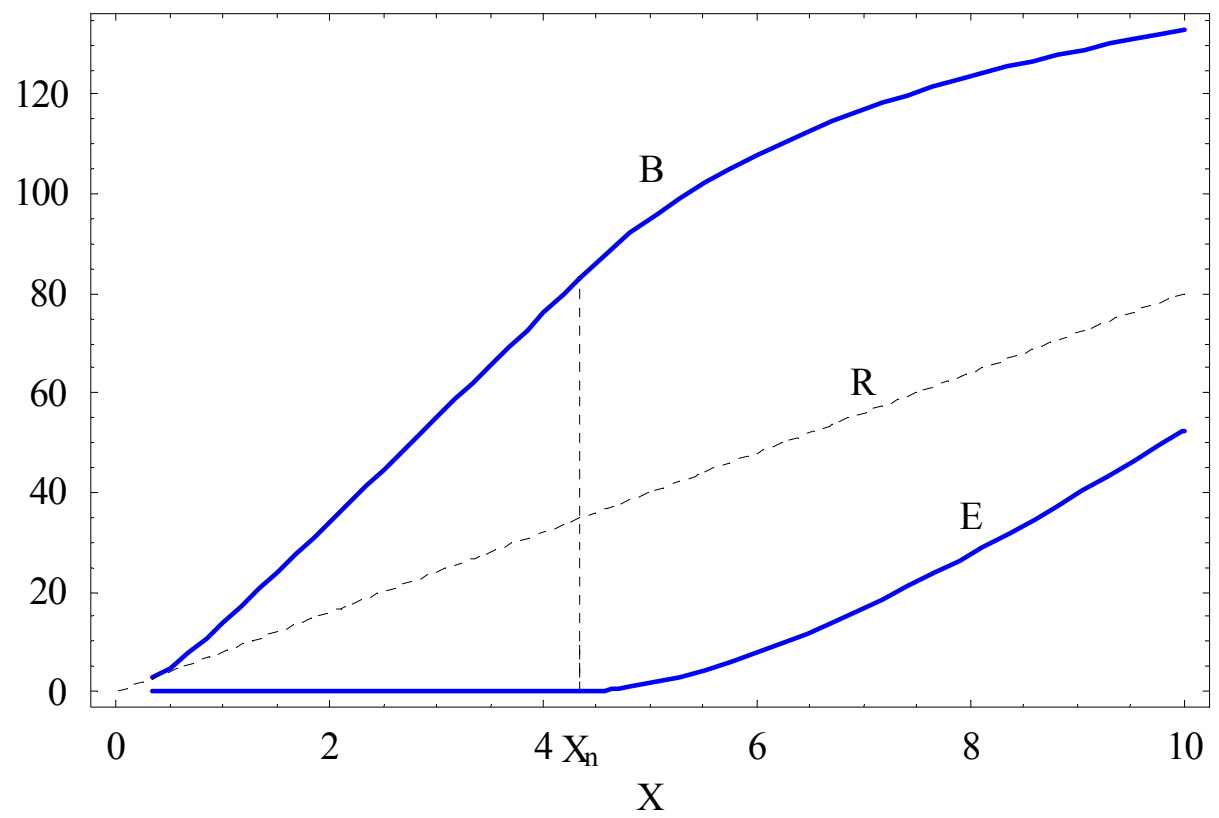

Figure 2: Bank Power Debt $B$ and Equity $E$ as a function of EBIT $X$ for a given coupon level $b$. It is assumed $X_{0}=20, b=10, r=6 \%, \mu=1 \%, \sigma=25 \%$, $\alpha=50 \%, \tau=20 \%$, and $\delta=5 \%$. Note that in the renegotiation region the bank is the residual claimant on the firm's cash flows and hence at the endogenous defaulttriggering EBIT level $X_{b}$ the value and the slope of bank bargaining power debt are equal to the corresponding value and slope of the firm's restructuring function $(1-\alpha)(1-\tau) X /(r-\mu)($ thin short-dashed line $)$. 


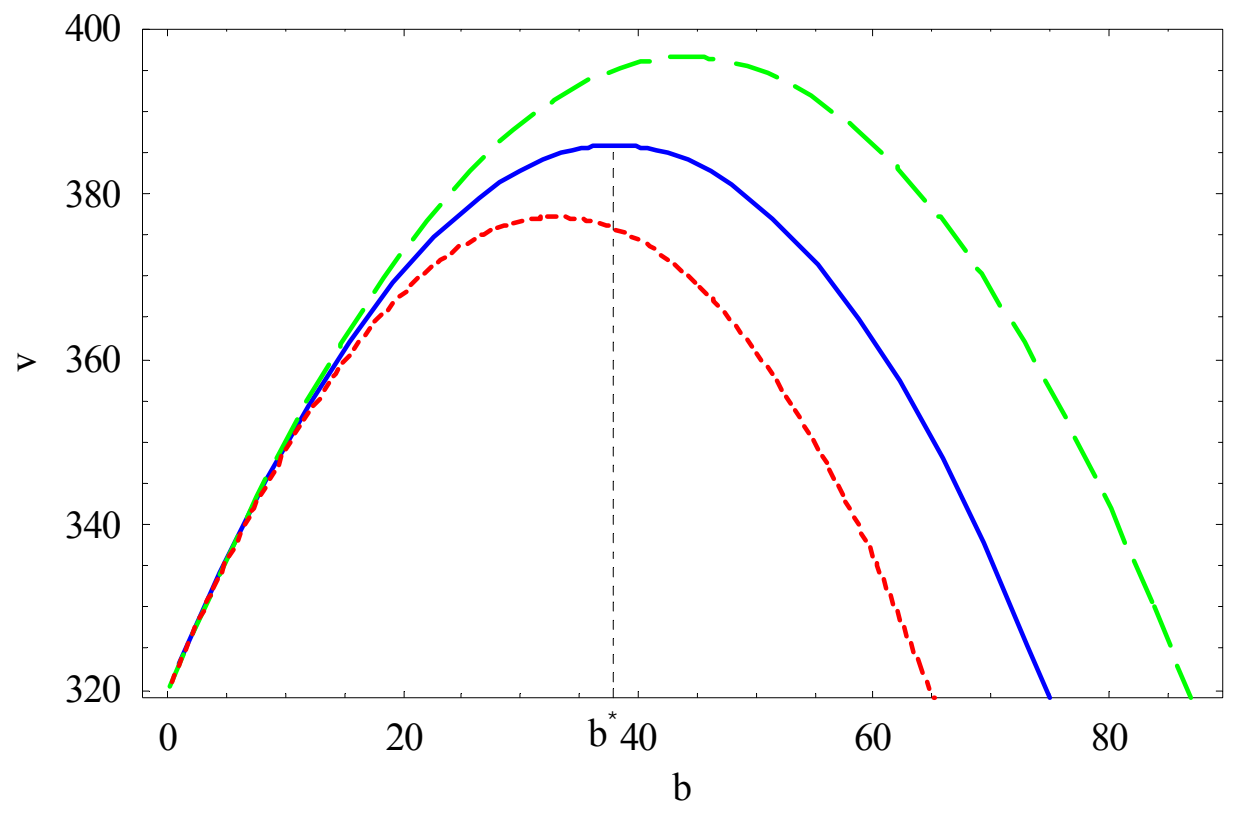

Figure 3: Total firm value $v$ of a Bank Power Debt firm as a function of promised coupon $b$ when the firm's negotiation cost varies: $\delta=1 \%$ (long-dashed line), $\delta=5 \%$ (solid line), and $\delta=10 \%$ (short-dashed line). It is assumed $X_{0}=20, r=6 \%, \mu=$ $1 \%, \sigma=25 \%, \alpha=50 \%$, and $\tau=20 \%$, implying $b^{*}=37.96$ and $X_{n}=16.47<X_{0}$ in the intermediate case. Note that optimal bank debt leverage $b^{*}$ depends on the magnitude of negotiation $\operatorname{costs} \delta$. 


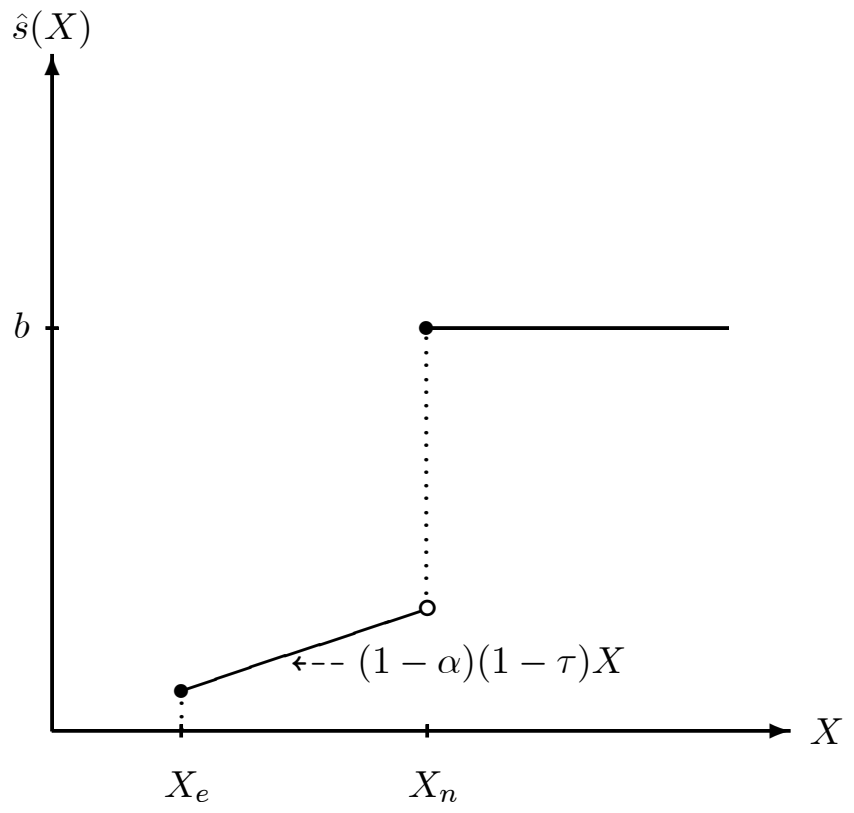

Figure 4: Strategic debt service $\hat{s}(X)$ as a function of EBIT $X$ in case of Senior Equity Power Debt $B$ with promised coupon $b$. It is assumed that either there are negotiation costs $(\delta>0)$ or the firm issued Market Debt $(c>0)$. Note that for positive $\delta$ or $c$, and $(\delta, c)$ sufficiently low relative to $b, \exists X_{d}(b, c ; \delta)$ such that default occurs endogenously and a nontrivial renegotiation region exists: $X_{e}(b, c ; \delta)<X_{n}$. 


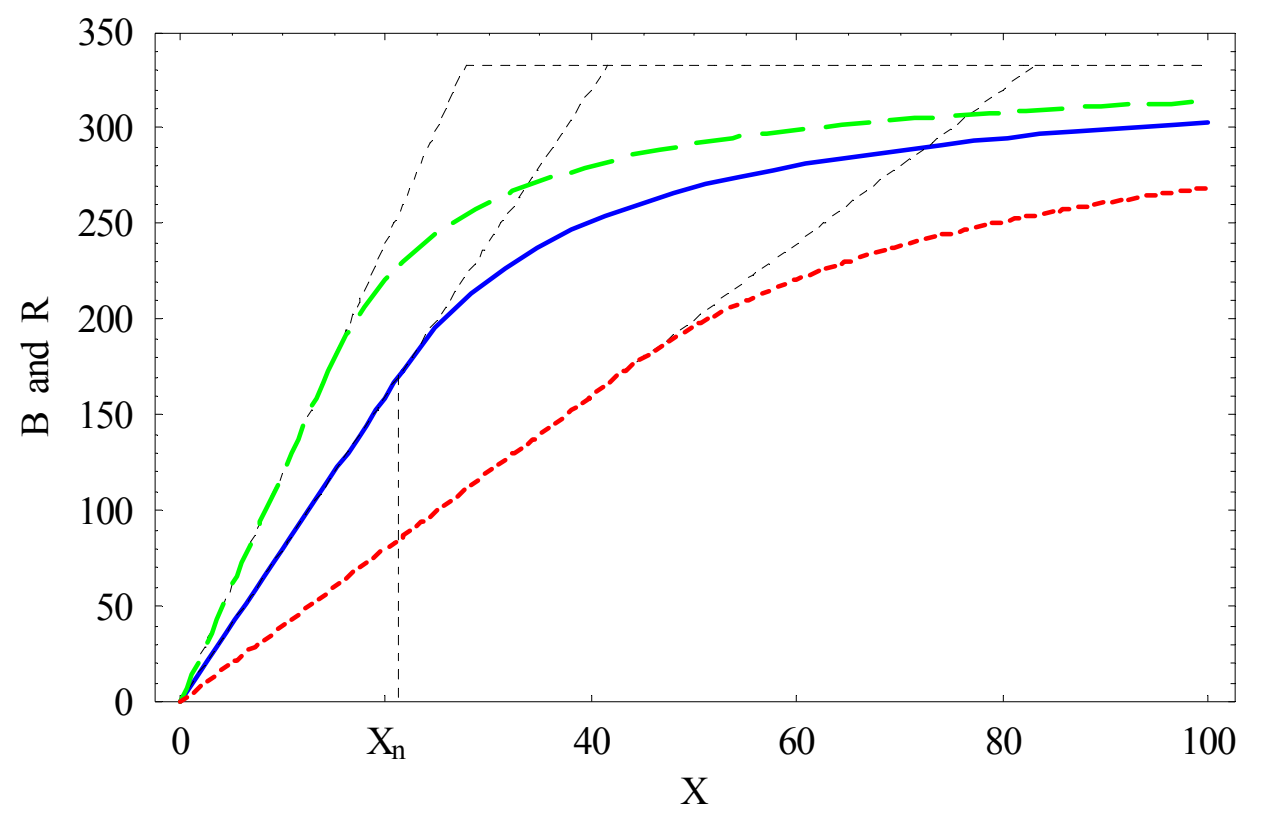

Figure 5: Senior Equity Power Debt $B$ and bank's reservation value $R$ as a function of EBIT $X$ for a given coupon level $b$ as the firm's bankruptcy costs vary: $\alpha=25 \%$ (long dashed line), $\alpha=50 \%$ (solid line), and $\alpha=75 \%$ (short-dashed line). It is assumed that $X_{0}=20, b=20, r=6 \%, \mu=1 \%, \sigma=25 \%, \tau=20 \%, \delta=0 \%$, $\eta=1$. Note that both the bank's reservation value $R$ (thin short-dashed lines) and the incentive compatible switch point $X_{n}$ depend on the firm's bankruptcy costs $\alpha$. 


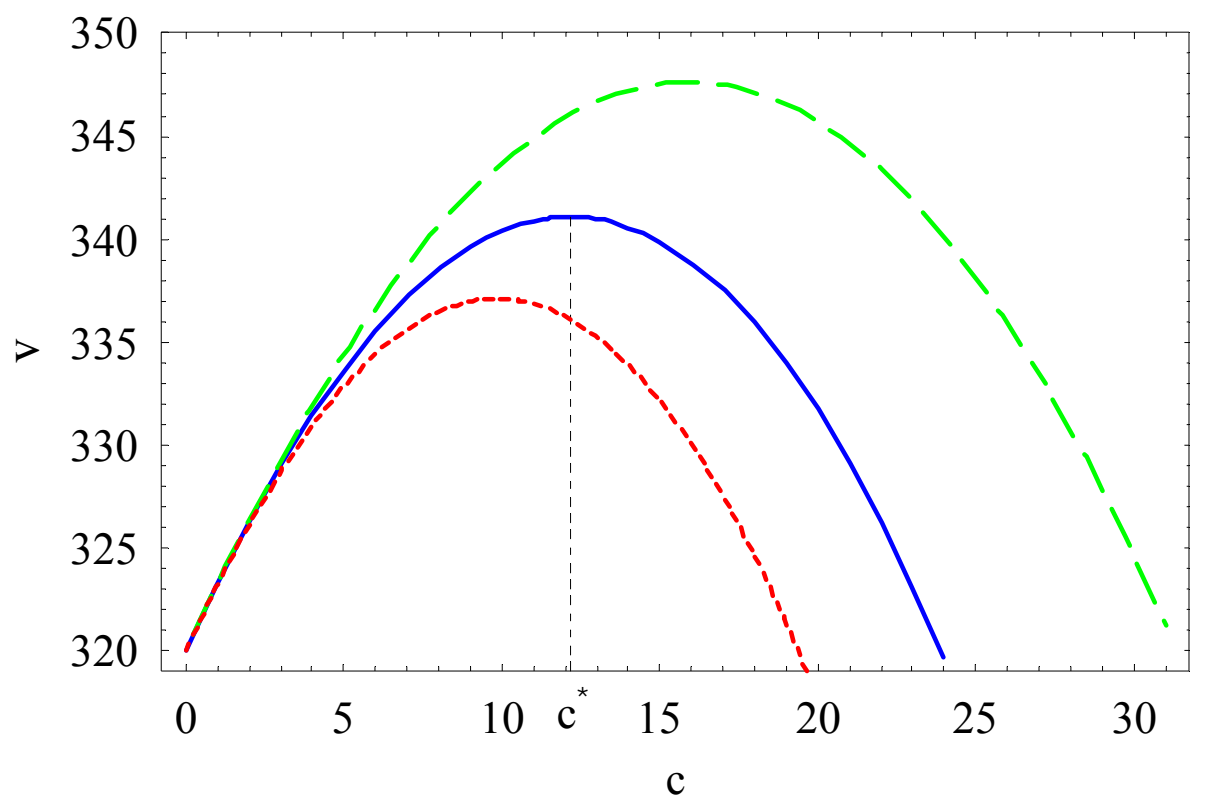

Figure 6: Total firm value $v$ of a Market Debt firm as a function of promised coupon payments $c$ when default costs vary: $\alpha=25 \%$ (long-dashed line), $\alpha=50 \%$ (solid line), and $\alpha=75 \%$ (short-dashed line). It is assumed $X_{0}=20, r=6 \%, \mu=1 \%$, $\sigma=25 \%, \tau=20 \%$. Oberve that the optimal coupon choice $c^{*}$ is decreasing in the firm's default costs $\alpha$. 


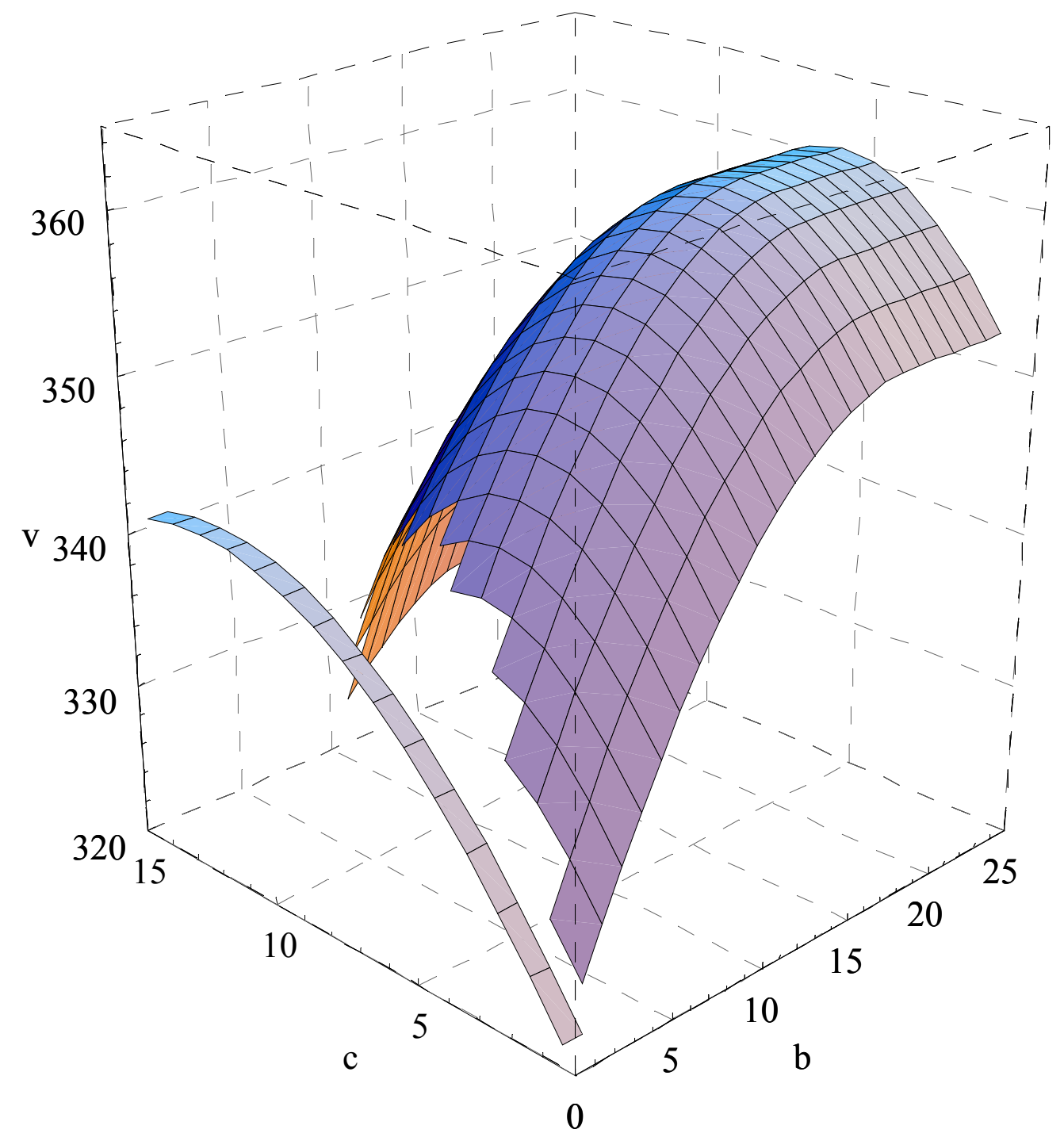

Figure 7: Total firm value $v$ as a function promised coupon payments to the bank $b$ and to the market $c$ when equity holders have all the bargaining power vis-à-vis the bank and the bank debt is senior $(\eta=1)$. It is assumed that $X_{0}=20, r=6 \%$, $\mu=1 \%, \sigma=25 \%, \alpha=50 \%, \tau=20 \%$, and $\delta=0 \%$, which implies that the unlevered firm is worth $V\left(X_{0}\right)=(1-\tau) X_{0} /(r-\mu)=320$. Note that there exists an interior firm value optimum for both classes of debt $v\left(b^{*}, c^{*}\right)=360.66$, where $b^{*} \geq 18.43$ and $c^{*}=4.99$. In the absence of renegotiation costs, this optimum is indeterminate regarding the optimal bank debt commitment. 


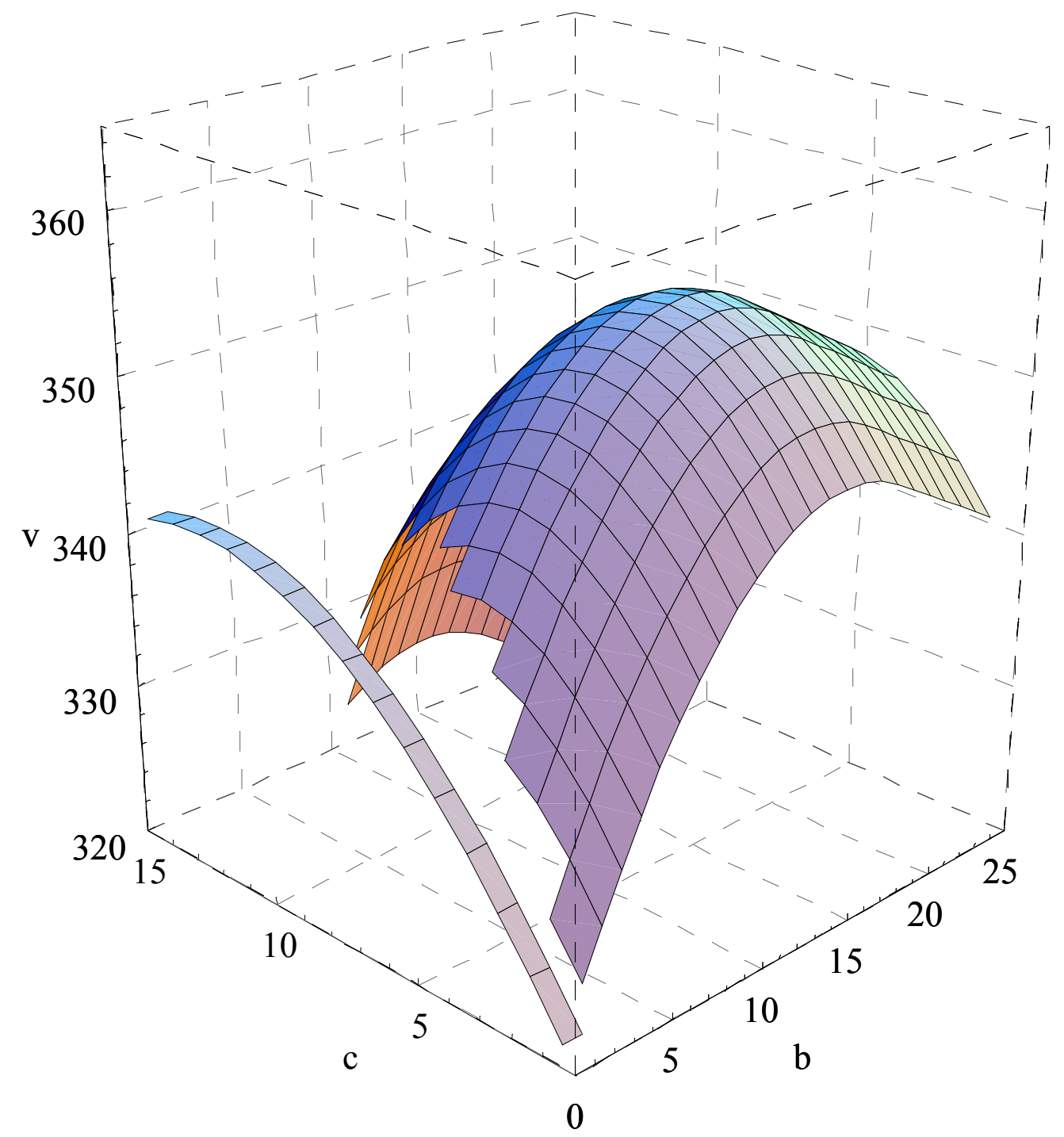

Figure 8: Total firm value $v$ as a function promised coupon payments to the bank $b$ and to the market $c$ when equity holders have all the bargaining power vis-àvis the bank and the bank debt is senior $(\eta=1)$. It is assumed that $X_{0}=20$, $r=6 \%, \mu=1 \%, \sigma=25 \%, \alpha=50 \%, \tau=20 \%$, and $\delta=5 \%$, which implies that the unlevered firm is worth $V\left(X_{0}\right)=(1-\tau) X_{0} /(r-\mu)=320$. Note that there exists a unique interior firm value optimum for both classes of debt $v\left(b^{*}, c^{*}\right)=354.57$, where $b^{*}=14.92$ and $c^{*}=4.99$. In the presence of renegotiation costs, the indeterminacy of Figure 7 regarding the optimal bank debt commitment disappears. 


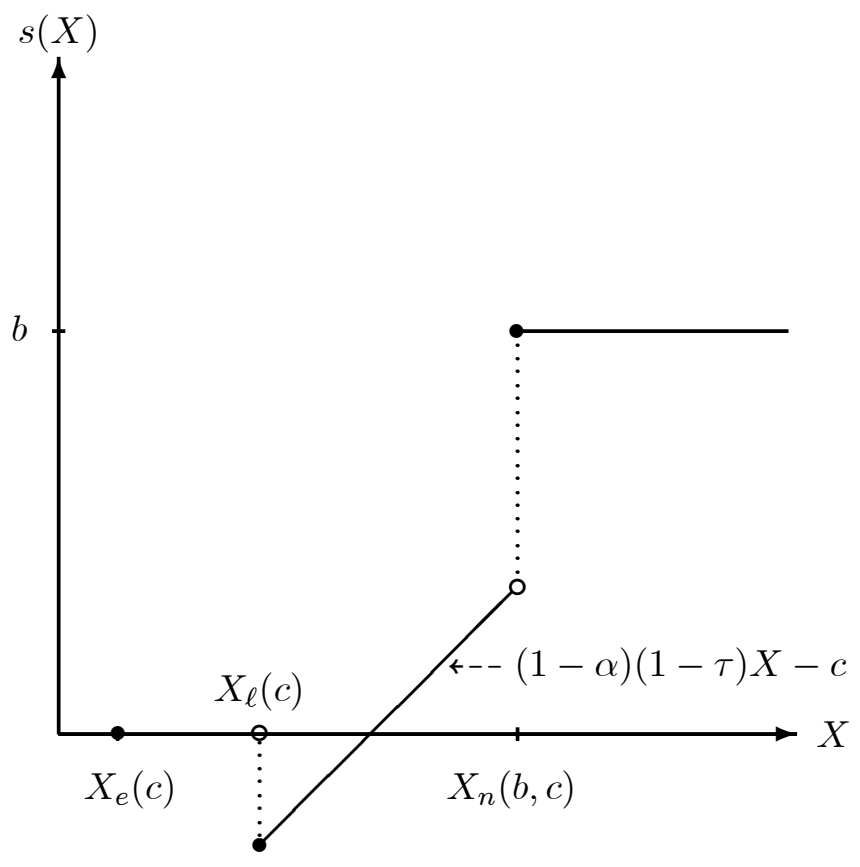

Figure 9: Strategic debt service $s(X)$ as a function of EBIT $X$ in case of Junior Equity Power Debt $B$ with promised coupon $b$. It is assumed that there is Market Debt $(c>0)$, but no negotiation costs $(\delta=0)$. 


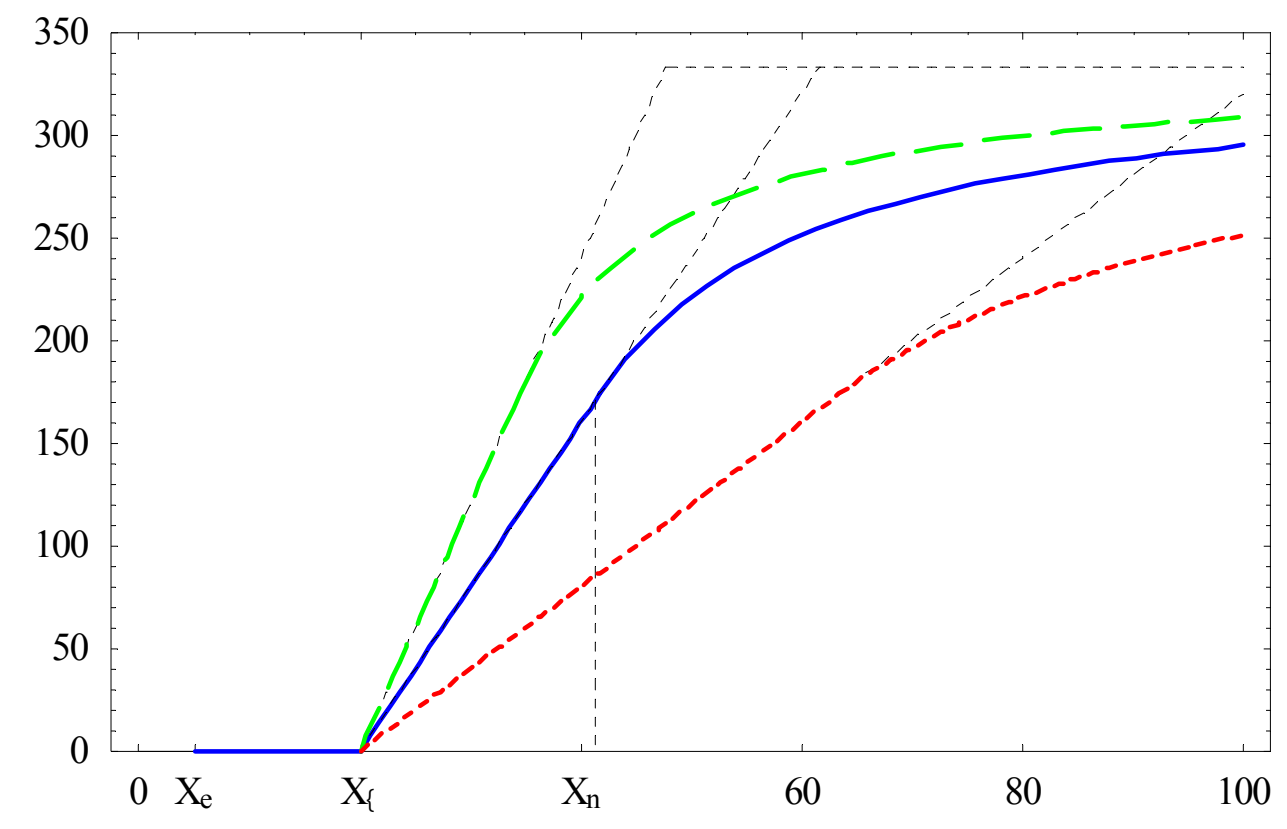

Figure 10: Junior Equity Power Debt $B$ and bank's reservation value $R$ as a function of EBIT $X$ for a given coupon level $b$ as the firm's bankruptcy costs vary: $\alpha=25 \%$ (long dashed line), $\alpha=50 \%$ (solid line), and $\alpha=75 \%$ (short-dashed line). It is assumed that $X_{0}=20, b=20, c=13, r=6 \%, \mu=1 \%, \sigma=25 \%, \tau=20 \%$, $\delta=0 \%$. Note that both the bank's reservation value $R$ (thin short-dashed lines) and the incentive compatible switch point $X_{n}$ depend on the firm's bankruptcy costs $\alpha$, while $X_{\ell}$ in addition depends on Market Debt's coupon flow $c$. 


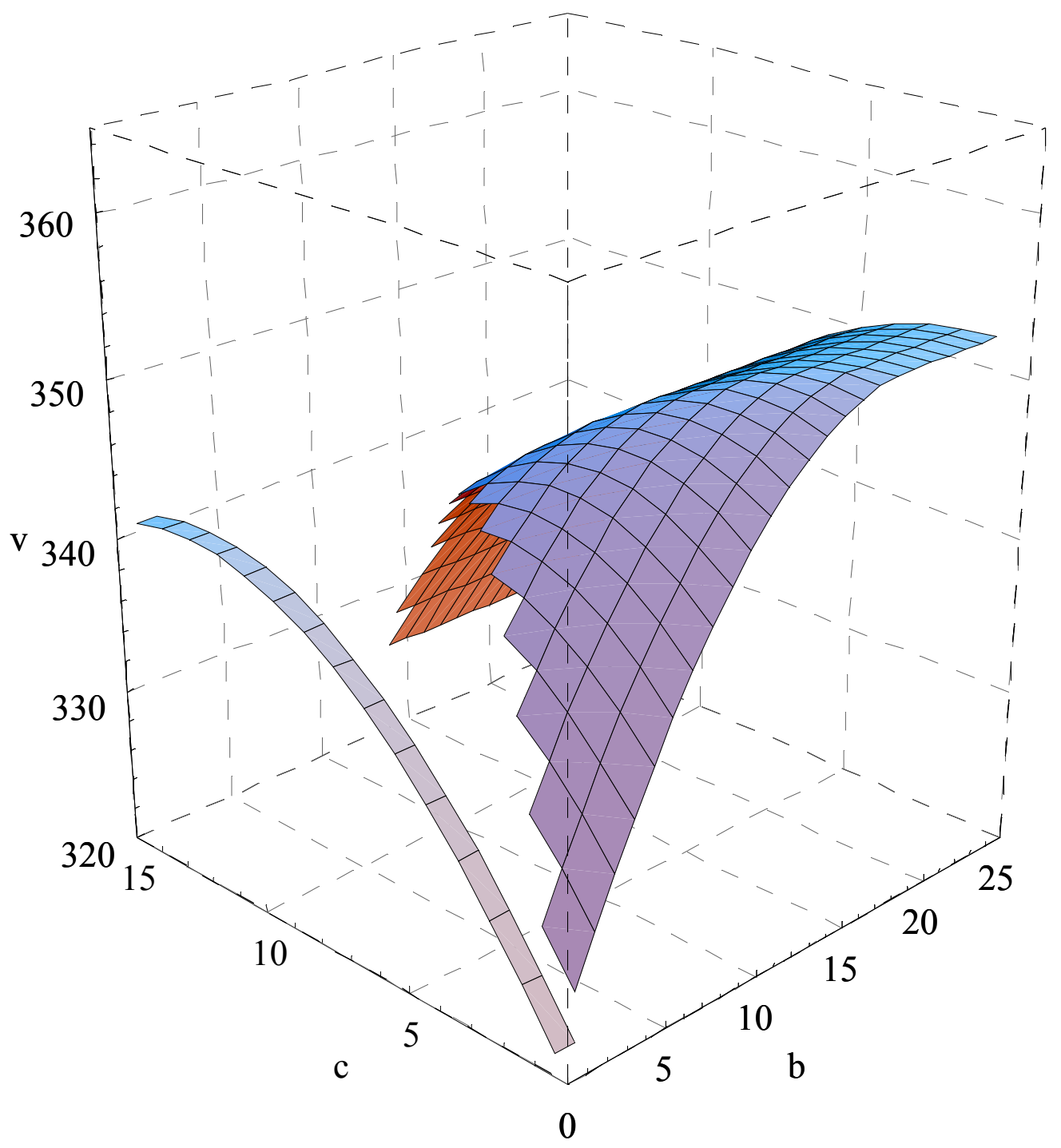

Figure 11: Total firm value $v$ as a function promised coupon payments to the bank $b$ and to the market $c$ when equity holders have all the bargaining power vis-à-vis the bank and the bank debt is junior. It is assumed that $X_{0}=20, r=6 \%, \mu=1 \%$, $\sigma=25 \%, \alpha=50 \%, \tau=20 \%$, and $\delta=0 \%$, which implies that the unlevered firm is worth $V\left(X_{0}\right)=(1-\tau) X_{0} /(r-\mu)=320$. Note that there exists a firm value optimum for both classes of debt $v\left(b^{*}, c^{*}\right)=352.01$, where $b^{*}=18.43$ and $c^{*}=0.00$. 


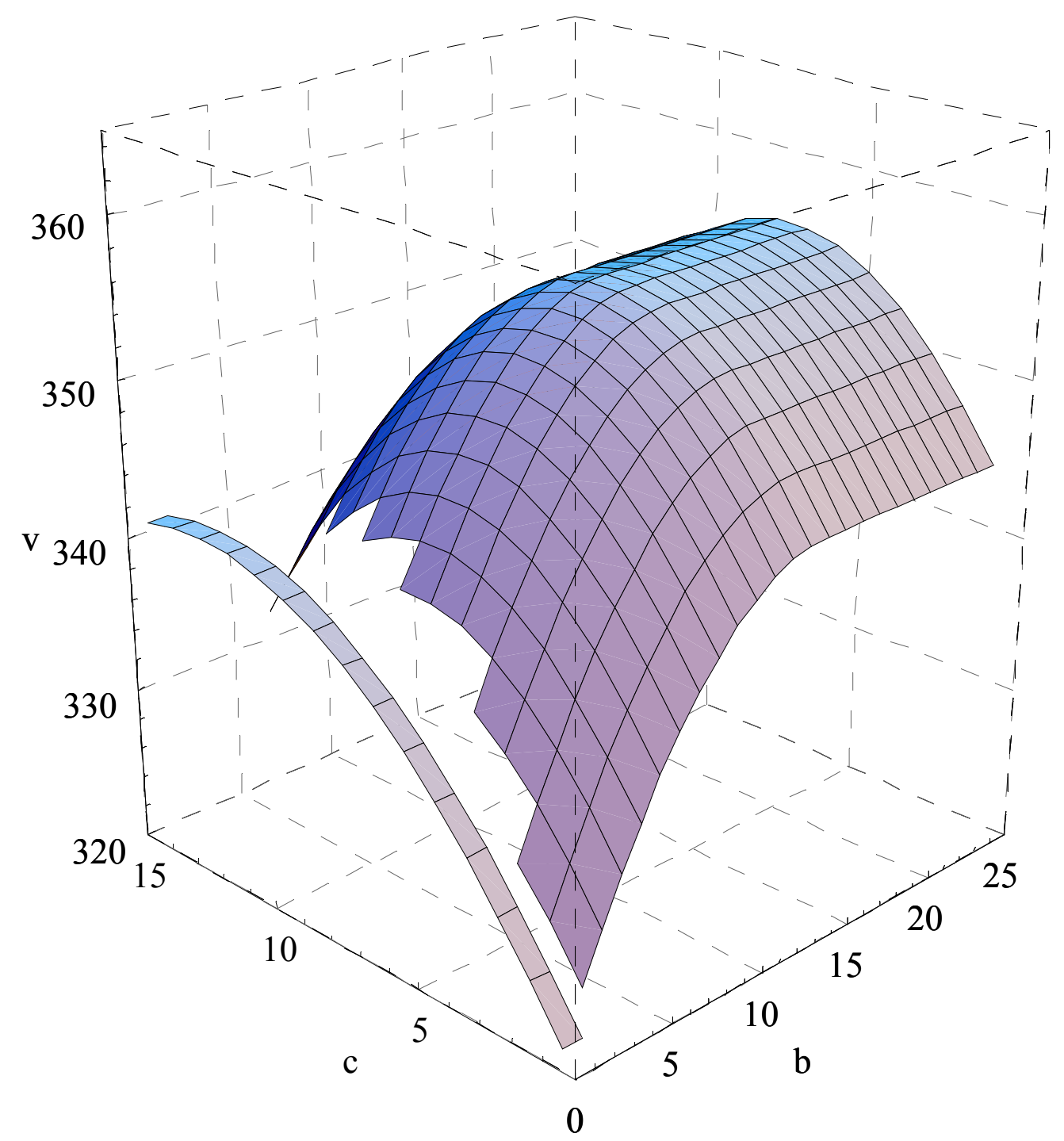

Figure 12: Total firm value $v$ as a function promised coupon payments to the bank $b$ and to the market $c$ when equity holders have all the bargaining power vis-à-vis the bank and the bank anticipates deviations from APR $(\eta=0.75)$. It is assumed that $X_{0}=20, r=6 \%, \mu=1 \%, \sigma=25 \%, \alpha=50 \%, \tau=20 \%$, and $\delta=0 \%$, which implies that the unlevered firm is worth $V\left(X_{0}\right)=(1-\tau) X_{0} /(r-\mu)=320$. Note that there exists an interior firm value optimum for both classes of debt $v\left(b^{*}, c^{*}\right)=355.37$, where $b^{*}=13.83$ and $c^{*}=6.55$. 


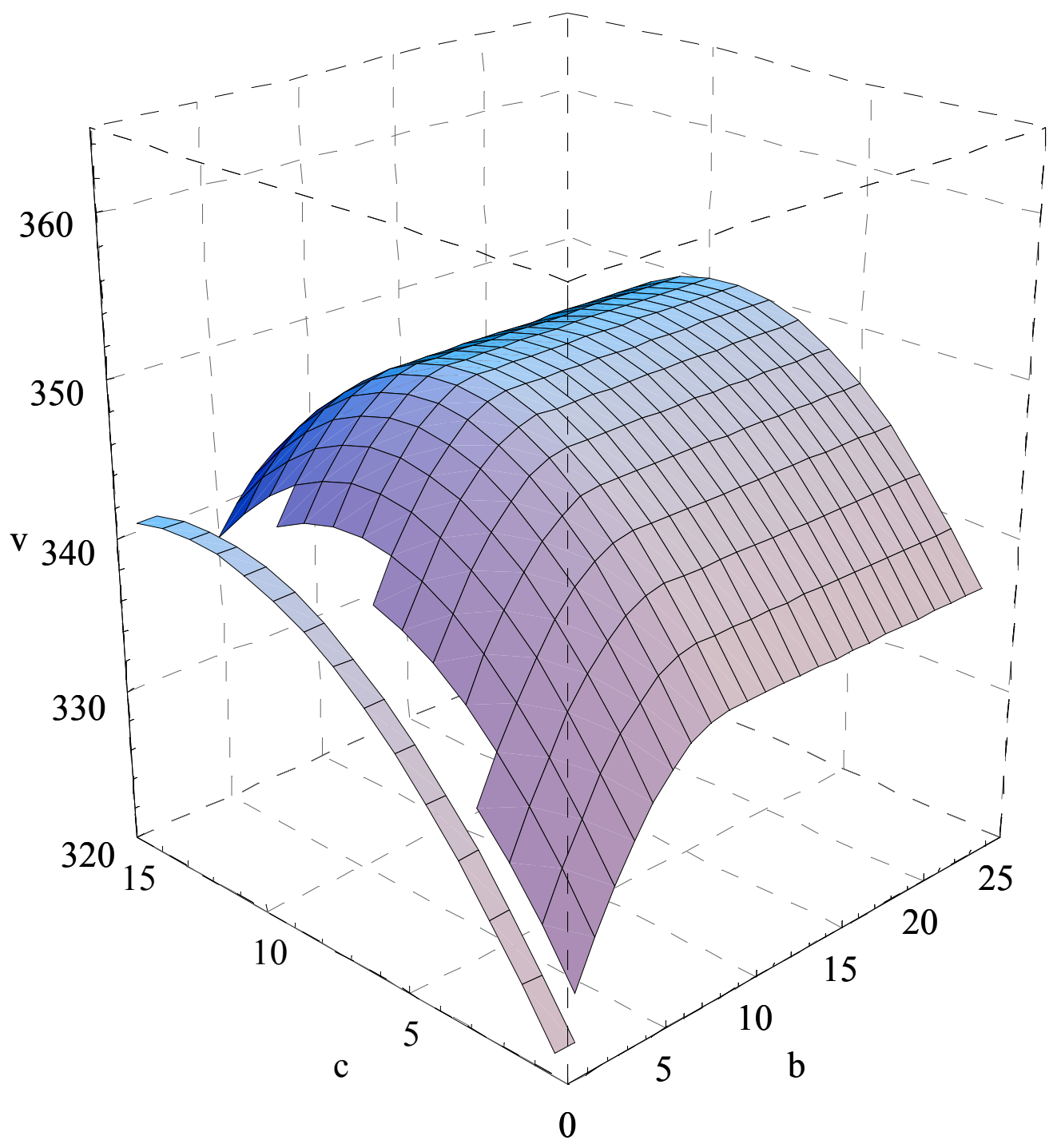

Figure 13: Total firm value $v$ as a function promised coupon payments to the bank $b$ and to the market $c$ when equity holders have all the bargaining power vis-à-vis the bank and the bank debt anticipates deviations from APR $(\eta=0.5)$. It is assumed that $X_{0}=20, r=6 \%, \mu=1 \%, \sigma=25 \%, \alpha=50 \%, \tau=20 \%$, and $\delta=0 \%$, which implies that the unlevered firm is worth $V\left(X_{0}\right)=(1-\tau) X_{0} /(r-\mu)=320.00$. Note that there exists an interior firm value optimum for both classes of debt $v\left(b^{*}, c^{*}\right)=$ 350.37 , where $b^{*}=9.22$ and $c^{*}=8.27$. 